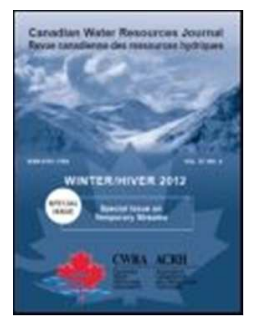

\title{
Using water stable isotopes for tracing surface and groundwater flow systems in the Barlow-Ojibway Clay Belt, Quebec, Canada
}

\begin{tabular}{|r|l|}
\hline Journal: & Canadian Water Resources Journal \\
\hline Manuscript ID & TCWR-2017-0012.R3 \\
\hline Manuscript Type: & Original Paper \\
\hline Date Submitted by the Author: & 08-Nov-2017 \\
\hline Complete List of Authors: & $\begin{array}{l}\text { Rey, Nathalie; Universite du Quebec en Abitibi Temiscamingue, Institut de } \\
\text { recherche en mines et environnement } \\
\text { Rosa, Éric; Universite du Quebec en Abitibi Temiscamingue, Groundwater } \\
\text { Research Group } \\
\text { Cloutier, Vincent; Université du Québec en Abitibi-Témiscamingue, Institut } \\
\text { de recherche en mines et en environnement; } \\
\text { Lefebvre, René; Institut national de la recherche scientifique, Centre Eau } \\
\text { Terre Environnement }\end{array}$ \\
\hline Keywords: & $\begin{array}{l}\text { Water stable isotopes, Groundwater, Surface waters, Precipitation, Boreal } \\
\text { region }\end{array}$ \\
\hline &
\end{tabular}


1 Using water stable isotopes for tracing surface and groundwater flow

2 systems in the Barlow-Ojibway Clay Belt, Quebec, Canada

3

For the use of the editors

\section{Paper \#:}

\section{Submitted on:}

Accepted on:

Application - Research - Commentary - Book Review:

\section{Copyright Held by:}

\section{T2012}




\section{Abstract}

20 This study aims to improve the understanding of surface and groundwater flow systems

21 based on water stable isotopes data in a 19,549 $\mathrm{km}^{2}$ region of the Barlow-Ojibway Clay

22 Belt, in western Quebec, Canada. The available geochemical database contains

23645 samples including precipitation, snow cores, surface waters, groundwater and

24 springs. All samples were analyzed for water stable isotopes $\left(\delta^{2} \mathrm{H}-\delta^{18} \mathrm{O}\right)$ and

25 complementary tritium analyses were conducted on 98 groundwater and spring samples.

26 Precipitations depict a clear temperature-dependent seasonal pattern and define a local 27 meteoric water line (LMWL) without a latitudinal trend in $\delta^{2} \mathrm{H}-\delta^{18} \mathrm{O}$. Samples collected

28 from the snowpack plot on the LMWL, suggesting that the bulk snowpack preserves the

29 isotopic composition of precipitation throughout the frozen period, prior to the spring

30 snowmelt. Surface water samples define a local evaporation line (LEL) and evaporation

31 over inflow (E/I) ratios range between $0 \%$ and $36 \%$. Groundwater and springs samples

32 are evenly distributed around the LMWL, suggesting that evaporation processes are

33 limited prior to infiltration and that surface waters do not significantly contribute to

34 groundwater recharge. Shallow unconfined aquifers present a greater variability in $\delta^{2} \mathrm{H}-$

$35 \delta^{18} \mathrm{O}$ compared to confined aquifers located further down gradient, suggesting the mixing

36 of varied recharge waters along the regional groundwater flow system. A three-

37 component mixing model based on isotopic and specific electrical conductivity data

38 allows the quantification of such mixing processes. The interpretation of isotopic data

39 constrains a regional-scale conceptual model of groundwater flow systems and describes

40 processes related to the timing of recharge, evaporation, mixing and discharge.

\section{Keywords:}

43 Water stable isotopes; Groundwater; Surface waters; Precipitation; Boreal region 


\section{Résumé}

46 Cette étude vise à mieux comprendre les systèmes d'écoulement dans une région de

$4719549 \mathrm{~km}^{2}$ au sein de la ceinture argileuse Barlow-Ojibway (ouest du Québec, Canada).

48 La base de données contient 645 échantillons analysés pour les isotopes stables de l'eau

$49\left(\delta^{2} \mathrm{H}-\delta^{18} \mathrm{O}\right)$ et inclue les précipitations, la neige au sol, les eaux de surface, les eaux

50 souterraines et les sources alors que 98 échantillons d'eau souterraine et de sources ont

51 été analysés pour l'activité tritium. La composition isotopique des précipitations présente

52 un cycle saisonnier dépendant de la température et définissant une droite locale des eaux

53 météoriques (DLEM) sans tendance $\delta^{2} \mathrm{H}-\delta^{18} \mathrm{O}$ reliée à la latitude. Les données de neige

54 au sol tombent sur la DLEM, ce qui suggère que le couvert nival préserve sa composition

55 isotopique en hiver, avant la fonte des neiges printanières. Les échantillons d'eau de

56 surface définissent une droite évaporatoire locale (DEL) et les rapports de l'évaporation

57 sur les flux intrants variant entre $0 \%$ et $36 \%$ à l'échelle régionale. Les données d'eau

58 souterraine et de sources suggèrent que les processus d'évaporation sont limités avant

59 l'infiltration et que les eaux de surface contribuent peu à la recharge. Les aquifères à

60 nappe libre peu profonds présentent une plus grande variabilité isotopique par rapport aux

61 aquifères à nappe captive situés en aval le long des lignes d'écoulement, ce qui suggère

62 une atténuation de la variabilité isotopique issue de la recharge le long des systèmes

63 régionaux. Un bilan géochimique appuyé sur les données isotopiques et de conductivité

64 électrique de l'eau permet de quantifier ces mélanges. L'interprétation des données

65 isotopiques permet de contraindre des modèles conceptuels représentant les systèmes

66 d'écoulement régionaux et de documenter les processus de recharge, d'évaporation, de

67 mélange et de résurgence. 
69 Groundwater plays key functions for several ecosystems and represents an essential source of 70 potable water for approximately half of the world's population (Taylor et al. 2013). Nevertheless,

71 groundwater resources have been heavily used for human water supply and agriculture for many 72 years on a global scale (WWAP 2009) and climate change will most likely affect the hydrological 73 cycle and aquifers in the near future (Green et al. 2011). Groundwater resources are expected to be 74 increasingly stressed in response to demographic growth and growing water demand (Vörösmarty 75 et al. 2000). It is estimated that by 2025 , nearly $50 \%$ of the world's population will be living in water-stressed regions (WHO 2017). Such considerations stress the critical need to better understand hydrogeological processes at various scales to support concrete actions aimed at protecting groundwater resources, to maintain ecosystems and meet water supply needs of future generations. Regionally and locally, groundwater protection must rely on land management strategies that are based on an appropriate understanding of the hydrogeological system. This is especially important in areas where most of the population relies on groundwater for potable water supply, as is the case for the Abitibi-Temiscamingue region in western Quebec. This region is renowned for its large eskers and moraines and for the remarkable quality of groundwater found

84 within the aquifers associated with these formations (Veillette et al. 2004; Collini et al. 2007).

85 However, these shallow unconfined aquifers are highly vulnerable to contamination and face increasing human pressures such as forest operations, sand and gravel extraction, former in-trench disposal sites, private and municipal wells and commercial water bottling (MRNF 2006; Nadeau et al. 2015; Cloutier et al. 2016). The impacts on the groundwater resources associated with eskers might also affect aquifers located down-gradient, further highlighting the need to better understand regional hydrogeological processes. In this context, providing regional stakeholders with a coupled

91 understanding of physical and geochemical conditions is mandatory to ensure that land-use decisions related to groundwater protection are based on reliable information.

93 Geochemical tracers are included in a wide spectrum of hydrological studies. They are increasingly

94 used to delineate flowpaths and quantify the processes affecting surface and groundwater resources

95 at various scales and in various regions of the world (e.g. Jeelani et al. 2013; Kortelainen and Karhu

96 2004; Wassenaar et al. 2011). Among the wide range of geochemical tracers that have been

97 exploited, water stable isotopes $\left({ }^{2} \mathrm{H}_{-}{ }^{18} \mathrm{O}\right)$ data have provided unique insights into hydrological 
98 processes (Araguás-Araguás et al. 2000; Gibson et al. 2005; Birks and Gibson 2009). The stable

99 isotopes of water are partitioned within a hydrological system, mainly in response to systematic

100 fractionation mechanisms occurring within the water cycle, including phase-change (solid-liquid101 vapour) processes, diffusion and rainout (Craig 1961; Rozanski et al. 1993; Gat 1996; Clark and 102 Fritz 1997). The isotopic composition of water is widely used in theoretical and applied 103 hydrological studies to document sources of atmospheric moisture and precipitation patterns 104 (Dansgaard 1964; Fritz at al. 1987), snow and ice-melting (Siegel and Mandle 1984), evaporation 105 processes in cold regions (Gat et al. 1994) and drylands (Kebede et al. 2009), sources mixing 106 (Ferguson et al. 2007; Wolfe et al. 2007) and groundwater recharge (Praamsma et al. 2009), among 107 other applications.

108 Cloutier et al. $(2013 ; 2015 ; 2016)$ provided a comprehensive assessment of groundwater resources 109 in the Abitibi-Témiscamingue region, within the framework of the Programme d'Acquisition de 110 Connaissances sur les Eaux Souterraines (PACES) supported by the Quebec Ministry of the 111 Environment. A regional scale conceptual hydrogeological model representing regional flowpaths 112 from unconfined aquifers, located in recharge areas, to confined aquifers, found beneath the clay 113 belt, was proposed through the course of these studies. Nevertheless, the proposed conceptual 114 model is mainly constructed on the basis of physical hydrogeological data, whereas geochemical 115 data have not been yet fully exploited, which leads to important limitations in the understanding of 116 regional hydrogeological dynamics. Fitting into the pre-established framework, this study aims to 117 improve the understanding of regional surface and groundwater flow systems in the southern 118 portion of the Barlow-Ojibway Clay Belt (Abitibi-Témiscamingue, Quebec, Canada) on the basis 119 of geochemical data. The present study focuses on the stable $\left({ }^{2} \mathrm{H}^{18}{ }^{18} \mathrm{O}\right)$ and radioactive $\left({ }^{3} \mathrm{H}\right)$ isotopes 120 of the water molecule. The proposed approach involves a regional-scale comprehensive assessment 121 of isotopic data within all hydrological components: precipitations, winter snowpack, surface 122 waters, groundwater and springs. The specific objectives of the present study are (1) to document 123 the atmospheric processes driving spatiotemporal variations in precipitation isotopic composition, 124 (2) to assess the potential interactions and mixing processes between surface waters and aquifers, 125 and (3) to decipher the mechanisms controlling the water isotopic variability in regional aquifers. 126 Ultimately, the data are interpreted to support an improved conceptual model of regional 127 groundwater flow systems representative of observed hydrogeological and geochemical conditions. 


\section{Study Area}

130 The study area (Figure 1) covers $19,549 \mathrm{~km}^{2}$ and corresponds to the municipalized territory of the 131 Abitibi-Temiscamingue region in Western Quebec, Canada. It encompasses the City of Rouyn132 Noranda and the Regional County Municipalities (RCM) of La Vallée-de-l'Or, Abitibi, Abitibi133 Ouest and Témiscamingue, for a total population of approximately 148,000 inhabitants (MAMROT 134 2016). It is estimated that more than $70 \%$ of this population relies on groundwater as a source of 135 domestic drinking water. The characteristics of the study area are briefly summarized below. 136 Further details about the hydrogeological framework can be found in Nadeau et al. (2015), Cloutier 137 et al. (2016), Nadeau et al. (2017) and within the geological maps of the Geological Survey of 138 Canada (Veillette 1986; 1987a; 1987b; Thibaudeau and Veillette 2005; Paradis 2005; 2007).

143 The landscape of the study area is relatively flat, with elevations generally ranging 144 between $280 \mathrm{~m}$ and $320 \mathrm{~m}$. The main positive reliefs correspond to heterogeneously 145 distributed bedrock outcrops, while the main depressions are associated with large lakes 146 (Abitibi, Témiscamingue and Simard; Figure 1). Despite its featureless landscape, the 147 region is crossed by the continental water divide separating surface waters of the 148 St. Lawrence River Basin (southern sector of the study area, Ottawa River watershed) 149 and those of the James Bay Basin (northern sector of the study area, Moose, Harricana 150 and Nottaway rivers watersheds).

\section{Climate and air masses}

152 The study region is characterized by a cold and humid continental climate with damp 153 summers, rather cold and long winters and a marked seasonality. The average monthly air 154 temperature remains below the freezing point from November to March (based on

155 Quebec Ministry of the Environment climate data; 1981-2010). The region is CWRJ 28230116_File000000_642833130.d6cx 
156 characterized by a significant latitudinal thermal gradient and a difference of $2.1{ }^{\circ} \mathrm{C}$ 157 between the average annual air temperature in Temiscamingue (south) and Abitibi (north) 158 was reported by Asselin (1995). This difference is likely imparted by latitude and by the 159 influence of the continental water divide that creates a discontinuity between the northern 160 and southern sectors of the study area. The presence of numerous lakes on a territory 161 characterized by a gentle relief likely favors the development of buffered microclimates. 162 Such a phenomenon is documented in the vicinity of lakes Abitibi and Témiscamingue 163 (Asselin 1995). Cloutier et al. (2015) provided daily air temperatures and vertical inflows 164 based on interpolated data provided by Centre d'Expertise Hydrique du Québec (CEHQ) 165 for a period ranging from 1900 to 2010 (Poirier et al. 2012). Vertical inflows correspond 166 to the fluxes of water from liquid precipitations and from the melting of snow, and 167 therefore to the fluxes of water that are available for infiltration or surface runoff. If the 168 temperature is below the freezing point, vertical inflows can be null even if precipitation 169 events are observed. In the absence of snow on the ground and when precipitations fall as 170 liquid water, vertical inflows correspond to precipitation. Yearly average vertical inflows 171 range between 790.5 and $856.5 \mathrm{~mm}$ at the regional scale. The vertical inflows associated 172 with snow falling during the frozen period will mainly be observed during spring 173 snowmelt. The greatest vertical inflows are recorded in April for most of the study area, 174 except for the northernmost sector where maximum values are observed in May, 175 probably due to later thaw (Cloutier et al. 2015). Minimum vertical inflows are recorded 176 in January over the entire region due to temperatures that generally remain below the 177 freezing point. Regional-scale monthly averages of daily maximum and minimum 178 temperatures reveal that the warmest month is July (with daily average minimum and 179 maximum temperatures of $11.2^{\circ} \mathrm{C}$ and $23.7^{\circ} \mathrm{C}$, respectively) and the coldest month is 180 January (with daily average minimum and maximum temperatures of $-23.3{ }^{\circ} \mathrm{C}$ and -10.3 $181{ }^{\circ} \mathrm{C}$, respectively). The mean annual precipitation ranges from $875 \mathrm{~mm}$ for La Vallée-de182 l'Or RCM and $989 \mathrm{~mm}$ in the city of Rouyn-Noranda (Quebec Ministry of the 183 Environment climate data).

184 The main air masses affecting western Quebec are (1) the cold and dry Arctic, (2) the 185 moist and warm Maritime-tropical air that originates from the Caribbean, subtropical 186 Atlantic and Gulf of Mexico and migrates northwards following the Mississippi and 
187 Missouri valleys before being deflected eastwards across the Great Lakes basin and (3)

188 the northern Pacific westerlies (Bryson 1966; Bryson and Hare 1974; Hare and Hay 189 1974). The Pacific westerlies are dominant in the continental climate for much of the year 190 (Hare and Hay 1974). Summers in the study area are warm and humid, reflecting the 191 dominance of Maritime-tropical air punctuated by intrusion of mild and dry westerlies.

192 Winters are influenced by Artic air masses that lead to cold and dry conditions (Bryson 193 and Hare 1974). The Abitibi-Temiscamingue region is characterized by weather 194 variability and instability reflecting the contribution of the different air masses. The 195 dominant winds generally originate from the northwest during winter and southwest 196 during summer. The polar jet stream, corresponding to the limit between the Arctic and 197 Maritime-tropical air masses, crosses the study area along a sinuous west-east pattern at 198 latitudes roughly corresponding to the position of the continental water divide.

\section{Hydrogeological framework}

200 The regional geological framework, as conceptually represented in Figure 2, is described

201 in details in numerous previous studies (Nadeau et al. 2015; Cloutier et al. 2016; Nadeau

202 et al. 2017; Veillette 1986; 1987a; 1987b; Veillette et al. 2004; Thibaudeau and Veillette 2005;

203 Paradis 2005; 2007) and it is thus only briefly presented here. Table 1 provides a summary

204 of the hydrological domains (atmosphere, surface, subsurface), components (precipitation

205 (snow, rain), surface water, groundwater, springs) and aquifers (granular (unconfined \&

206 confined), fractured rock (unconfined \& confined)) that are discussed in this study, in

207 relation with the main geological units of the region. The bedrock of the study area

208 (geological unit A in Figure 2) is composed of a wide variety of igneous, metamorphic

209 and metasedimentary rocks of the Abitibi and Pontiac sub-provinces, both components of

210 the Superior Geological Province. Groundwater flow within the bedrock is controlled by

211 the architecture of structural discontinuities. Cloutier et al. (2016) estimated hydraulic

212 conductivities ranging between $10^{-9}$ and $10^{-4} \mathrm{~m} / \mathrm{s}$ for this unit. However, there is currently

213 no sufficient data to propose a regional-scale interpretation of bedrock hydrogeological

214 characteristics based on structural interpretations. Nevertheless, Rouleau et al. (1999)

215 proposed that groundwater flow within the bedrock of the study area is most likely

216 restricted to depths shallower than $75 \mathrm{~m}$ where sub-horizontal fractures are sufficiently 
217 interconnected to allow significant groundwater flow. Most of the domestic wells of the 218 region are withdrawing groundwater from this unit using wells that are cased through 219 surficial sediments and open across the bedrock.

Table 1. Summarized characteristics of the regional hydrogeological framework

223 The oldest unconsolidated unit of the region corresponds to the till associated with the 224 last glaciation (geological unit B in Figure 2). It is recognized as a compact heterometric 225 geological unit characterized by a matrix composed of sand, silt and clay (Cloutier et al. 226 2015). The hydrogeological characteristics of this unit are poorly documented because it 227 is rarely exploited for groundwater supply, although it is not considered as a regional 228 aquitard (Cloutier et al., 2013; 2015). This till unit is overlain in places by glaciofluvial 229 sediments. The coarse grained glaciofluvial sediments (eskers and moraines; geological 230 unit $\mathrm{C} 1$ in Figure 2) of the region were mainly deposited at the emergence of subglacial 231 meltwater within proglacial Lake Barlow-Ojibway (Nadeau et al. 2015). These 232 formations are characterized by relatively high hydraulic conductivities, $10^{-6}$ to $10^{-1} \mathrm{~m} / \mathrm{s}$ 233 according to Cloutier et al. (2016), and constitute the most productive unconfined 234 aquifers of the region (Nadeau et al. 2015). Other glaciofluvial sediments, mainly 235 consisting in finer sand and gravel, are also widespread between the main eskers and 236 moraines of the region (geological unit C2 in Figure 2). This unit is generally 237 characterized by hydraulic conductivities that are slightly lower than that of the eskers 238 and moraines (Cloutier et al. 2013; 2015; 2016). The glaciofluvial sediments are covered 239 in places by fine grained deep-water glaciolacustrine sediments deposited within 240 proglacial Lake Barlow-Ojibway (identified as the Clay Belt in Figure 1; geological unit 241 D in Figure 2). Owing to its structure consisting in centimeter-scale alternating layers of 242 clay and silt (varves), this unit is considered as a regional aquitard (Cloutier et al. 2015), 243 although silt horizons may allow preferential sub-horizontal groundwater flow.

244 Sublittoral sands and beach or eolian sediments (geological unit E in Figure 2) overlying 245 the fine grained deep-water glaciolacustrine sediments are spatially associated with the 
246 glaciofluvial deposits whereas organic deposits (geological unit $F$ in Figure 2) are 247 widespread across the region, with large peatlands often developing on the flanks of 248 eskers and moraines.

249 Given this geological framework, and based on previous work from Cloutier et al. (2016) 250 and Nadeau et al. (2017), four main types of aquifers are distinguished within the study 251 region (Figure 2) and used to regroup the isotopic data:

252

270 These water balance calculations are based on the vertical inflows (VI) provided by 271 Poirier et al. (2012) and on hypotheses associated with the regional hydrogeological 
272 framework for estimating runoff $(R)$, water storage within the unsaturated soil $\left(\Delta W_{S}\right)$ and 273 evapotranspiration (ET). Runoff coefficients were estimated according to land use, soils 274 characteristics and surface slopes, among others. Potential evapotranspiration rates were 275 quantified using the Thornthwait (1944) equation with climate data from Poirier et 276 al. (2012). The water storage within the unsaturated zone and the available water for 277 transpiration were evaluated for the different soils based on estimates of water retention 278 capacities, wilting points and thickness of the root zone. The calculated recharge rates 279 range between less than $91 \mathrm{~mm} / \mathrm{yr}$ in sectors where fine-grained deep-water 280 glaciolacustrine sediments are found and more than $300 \mathrm{~mm} / \mathrm{yr}$, mainly in sectors 281 corresponding to eskers / moraines and other unconfined granular aquifers. Overall, 282 maximum recharge rates are observed during the snowmelt period whereas the lowest 283 rates are recorded throughout the winter period, when temperatures are below the 284 freezing point.

Figure 2. Regional hydrogeological conceptual model and water sampling scheme used to characterize the isotopic signature of all hydrological system components

Methods

290 Sampling procedures and in situ measurements

291 Overall, 645 water samples were analyzed for their isotopic composition $\left(\delta^{2} \mathrm{H}-\delta^{18} \mathrm{O}\right)$ as 292 part of this study, over a period ranging from 2006 to 2015 (Figure 1; Table 2). Table 2 293 provides a summary of the available data and associated sampling periods. From this 294 dataset, 98 water samples (only springs and groundwater) were also analyzed for their 295 tritium $\left({ }^{3} \mathrm{H}\right)$ content, over a period ranging from 2006 to 2011 . The procedures associated 296 with the sampling of precipitations, the snowpack, surface waters, springs and 297 groundwater are presented separately below. 


\section{Precipitation monitoring}

300 Monthly composite precipitation samples were collected at four monitoring stations

301 within the study area (Figure 1; Station 1 = Béarn; Station 2 = Montbeillard; Station $3=$

302 Sainte-Hélène-de-Mancebourg; Station 4 = Amos). Samples were collected monthly from

303 July 2013 to 2015 at stations 1-2-3 (Figure 1), three sites included in the Quebec Ministry

304 of the Environment Climate Monitoring Network. Rainfall samples were collected using

305 a $10.1 \mathrm{~cm}$ inside diameter All Weather P-2000 standard rain gauges from Productive

306 Alternatives. A thin layer (approximately $1 \mathrm{~cm}$ ) of paraffin oil (Mineral Oil, Light

307 (NF/FCC), Fisher Chemical) was added to the rain gages to prevent evaporation and

308 plastic screens were installed at the base of the rain gauge funnels to block debris and

309 insects. Snowfall samples were collected owing to the participation of local operators /

310 observers associated with the monitoring network. These observers are mandated to make

311 measurements of snow (calculated in terms of equivalent water) intercepted by shielded

312 Nipher snow gauges. Snow samples are collected daily at stations 1 and 3 (but not at

313 station 2 owing to logistical constraints), left to melt overnight and subsequently stored in

$3141 \mathrm{~L}$ high density polyethylene (HDPE) bottles. Daily samples are mixed in order to obtain

315 composite monthly samples. Paraffin oil (Mineral Oil, Light (NF/FCC), Fisher

316 Chemical) is added to the bottles in order to prevent evaporation. The Amos monitoring

317 station (Station 4), in operation from September 2009 to 2015, is located on the roof of

318 the university campus and is not associated with the MDDELCC climate network. At this

319 station, rain and snow samples are collected daily using a $30 \mathrm{~cm}$ ID bucket. Snow

320 samples were left to melt overnight at $4{ }^{\circ} \mathrm{C}$ and subsequently stored in HDPE bottles.

321 Daily samples were combined to produce a monthly composite sample. In all cases, the

322 volume of monthly composite samples was first evaluated in the laboratory and smaller

323 aliquots were subsequently stored in $60 \mathrm{ml}$ HDPE bottles and kept at $4{ }^{\circ} \mathrm{C}$ until stable

324 isotopes $\left(\delta^{2} \mathrm{H}-\delta^{18} \mathrm{O}\right)$ analyses.

\section{Samples from the Snowpack}

326 A sampling campaign was carried out in March 2014 in order to retrieve cores from the

327 snowpack accumulated throughout the winter. Sampling sites were selected in the 
328 western part of the study region in an effort to collect data in the vicinity of the grid 329 points used by the CEHQ for calculating vertical inflows (Poirier et al. 2012). At each 330 site, a straight trench varying in length from $5 \mathrm{~m}$ to $6 \mathrm{~m}$ was first dug in a direction 331 oriented perpendicular to the wind. Snow cores $(n \geq 5)$ were subsequently sampled at $332 \leq 1 \mathrm{~m}$ intervals, on the side of the trench facing the dominant wind. Snow cores were 333 collected using $4.2 \mathrm{~cm}$ ID x $1.6 \mathrm{~m}$ length HDPE tubes allowing the collection of the 334 snowpack over its entire height. Samples were weighed on site using a Mettler Toledo 335 digital scale with a precision of $0.0001 \mathrm{~kg}$ in order to calculate equivalent water contents. 336 For each site, the collected snow cores were transferred and combined within wide neck 337 HDPE bottles in order to obtain $>800 \mathrm{~g}$ composite samples. Samples were kept frozen 338 within the tightly sealed wide neck bottles during the field campaign and subsequently 339 left to melt overnight at room temperature. The melted samples were filtered using $340 \quad 0.45 \mu \mathrm{m}$ Waterra FHT cartridges to remove soil particles and/or windblown debris 341 embedded in the snow. The filtered samples were transferred into 30-60 ml HDPE 342 containers and stored at $4{ }^{\circ} \mathrm{C}$ until stable isotopes $\left(\delta^{2} \mathrm{H}-\delta^{18} \mathrm{O}\right)$ analyses.

\section{Surface waters}

345 Surface water samples were collected in July 2009 and from July to October, 2013. 346 Rivers and streams were sampled near the central part of the main channel, at depths of 347 0.5-1.5 m below surface. In situ parameters $(\mathrm{pH}$, dissolved oxygen, conductivity, redox 348 potential and temperature) were measured using a YSI 556 MPS probe, a few centimeters 349 downstream of the sampling point. A $7.32 \mathrm{~m}$ NASCO Swing Sampler telescopic pole 350 equipped with a 1 L HDPE bottle was used to collect samples from the banks of small 351 rivers and streams. The perch and its container were rinsed on site at a point located a few 352 meters downstream of the sampling site. Whenever sampling from a bridge was possible, 353 the samples were collected using 1 L Waterra ecobailers. A nylon wire equipped with a 354 float was attached to the bailer to indicate the sampling depth. The bailers were 355 systematically rinsed on site, with water from rivers prior to sampling. Some of the 356 streams and rivers were sampled immediately at the outlet of large lakes (Table 3). These 
357 samples are used to provide an instantaneous estimate of the isotopic composition of 358 water in the epilimnon at the outlet of the lake. Grab samples were also collected from 16 359 additional lakes, including 14 kettle lakes (Table 3). The samples from Lake 360 Témiscamingue were collected from a boat, at a depth of $1 \mathrm{~m}$ using a NASCO Swing 361 Sampler telescopic pole equipped with a 1 L HDPE bottle. The samples from Lake Tee 362 were collected from a boat, approximately $1 \mathrm{~m}$ below the surface, using a plastic tubing 363 equipped with an inertial valve. The samples from kettle lakes were collected from the 364 shoreline, approximately $1 \mathrm{~m}$ below surface, using a NASCO Swing Sampler telescopic 365 pole equipped with a 1 L HDPE bottle.

\section{Table 3. Summary of surface waters sampling conditions}

367 All surface water samples were filtered immediately after collection using $0.45 \mu \mathrm{m}$ 368 Waterra FHT. The samples collected for stable isotopes analyses $\left(\delta^{2} \mathrm{H}-\delta^{18} \mathrm{O}\right)$ were stored 369 in 30-60 $\mathrm{ml} \mathrm{HDPE}$ bottles and kept at $4{ }^{\circ} \mathrm{C}$ until analysis.

370 Springs

371 Groundwater springs were sampled between July 2009 and September 2011 through the 372 course of a previous study (Castelli 2012). These samples are associated with the 373 Vaudray-Joannès, Launay and Saint-Mathieu-Berry eskers and with the Harricana 374 Moraine. Other spring samples were collected during the summer of 2013. These 375 correspond to springs that are equipped for drinking water supply. All spring samples 376 were filtered immediately after collection using $0.45 \mu \mathrm{m}$ Waterra FHT carthridges. The 377 in situ parameters ( $\mathrm{pH}$, dissolved oxygen, specific electrical conductivity (SEC), redox 378 potential and temperature) were measured on site using a multi-parameter probe. Further 379 details about the sampling methodology can be found in Castelli (2012). The samples 380 collected for stable isotopes analyses $\left(\delta^{2} \mathrm{H}-\delta^{18} \mathrm{O}\right)$ were stored in 30-60 ml HDPE bottles. 381 The samples collected for tritium $\left({ }^{3} \mathrm{H}\right)$ analyses were stored in 1 L HDPE bottles.

382 Sampling bottles for stable isotopes analyses $\left(\delta^{2} \mathrm{H}-\delta^{18} \mathrm{O}\right)$ and tritium $\left({ }^{3} \mathrm{H}\right)$ analyses were 383 filled to the top with no head space and kept at $4{ }^{\circ} \mathrm{C}$ until analysis. 
385 Municipal, private and observation wells were sampled during this study. The targeted 386 wells were commonly identified using the Quebec Ministry of the Environment water 387 well databases, including the Hydrogeological Information System (HIS). 388 Complementary information about the characteristics of the sampled wells was obtained 389 from the private owners or from municipal employees. Well logs were used to document 390 the characteristics of the sampled observation wells. Two conditions had to be met prior 391 to groundwater samples collection: the infrastructures had to be purged of a minimal 392 volume of water and the monitored in situ parameters had to reach predefined stability 393 criteria. Water was therefore systematically purged from domestic and observation wells 394 before sample collection. This procedure allows draining the stagnant water from the 395 infrastructure to obtain a water sample that represents groundwater from the aquifer. For 396 private wells, it was assumed that water was withdrawn on a regular basis and that the 397 minimal purge could be limited to the volume of the pressurized reservoirs. The purging 398 was done from taps supplying untreated water. The minimum purging volume for 399 observation wells corresponded to three times the total volume of water stored within the 400 well and its gravel pack. In municipal wells, it was assumed that water is withdrawn at a 401 sufficient rate to prevent stagnation within infrastructures and that no minimal purge was 402 required. During the purge, in situ parameters $(\mathrm{pH}$, dissolved oxygen, SEC, redox 403 potential and temperature,) were measured using a multi-parameter probe. The samples 404 were retrieved only after all of the in situ parameters had reached the stability criteria 405 reported in Table 4 for three consecutive measurements separated by five minutes 406 intervals. The samples collected for stable isotopes analyses $\left(\delta^{2} \mathrm{H}-\delta^{18} \mathrm{O}\right)$ were stored in 407 30-60 $\mathrm{ml} \mathrm{HDPE}$ bottles and kept at $4{ }^{\circ} \mathrm{C}$ until analysis. The samples collected for tritium $408\left({ }^{3} \mathrm{H}\right)$ analyses were stored in 1 L HDPE bottles. Sampling bottles for tritium $\left({ }^{3} \mathrm{H}\right)$ analyses 409 were filled under water in a bucket and capped under water with no head space following 410 a filling procedure described by the USGS and kept at $4{ }^{\circ} \mathrm{C}$ until analysis. 


\section{Analytical procedures}

415 Water samples were analyzed for $\delta^{2} \mathrm{H}$ and $\delta^{18} \mathrm{O}$ at the stable isotopes laboratory of the 416 Geotop-UQAM research center in Montreal, Canada. Measurements were made using a 417 dual inlet Micromass Isoprime ${ }^{\mathrm{TM}}$ isotope ratio mass spectrometer coupled to an 418 Aquaprep $^{\mathrm{TM}}$ system. For oxygen and hydrogen isotopic analyses, $200 \mu 1$ of water were 419 transferred into septum vials and equilibrated in a heated rack with a known volume of $420 \mathrm{CO}_{2}\left(\mathrm{H}_{2}\right.$ in the case of hydrogen analyses, with a platinum catalyst). The isotopic 421 compositions of samples were corrected using internal reference waters $\left(\delta^{18} \mathrm{O}=-6.71 \%\right.$, $422-13.98 \%$ and $-20.31 \%$; $\delta^{2} \mathrm{H}=-51.0 \%$, $-99.0 \%$ and $-155.4 \%$ ) calibrated on the VSMOW423 SLAP scale (Coplen 1996). Reference waters were systematically analyzed between 424 series of samples in order to check for instrumental stability. The analytical uncertainty is $425 \leq 1 \%$ for $\delta^{2} \mathrm{H}$ and $\leq 0.05 \%$ for $\delta^{18} \mathrm{O}$ at the $1 \sigma$ level. Values are reported in permil units 426 (\%) against the Vienna Standard Mean Ocean Water standard (VSMOW). Water samples

427 for tritium $\left({ }^{3} \mathrm{H}\right)$ analyses were measured by liquid scintillation counting (LSC) at the 428 Environmental Isotope Laboratory of the University of Waterloo, Canada. The detection 429 limit for enriched samples is 0.8 tritium units (TU).

\section{Data organization and statistical analyzes}

431 In order to support the interpretation of results, the isotopic data are organized according

432 to the main hydrological components and aquifers that were presented previously 433 (Table 1; Figure 2). Overall, eight distinct groups are identified for segregating the 434 isotopic data. The latter include (with numbers corresponding to those reported in 435 Figure 2) samples corresponding to (1) precipitation, (2) the snowpack, (3) surface 436 waters, (4) springs, (5) unconfined granular aquifers, (6) confined granular aquifers, (7) 437 unconfined fractured rock aquifers and (8) confined fractured rock aquifers. The basic 438 statistical analyses conducted on the dataset and related plots were performed using the 439 Statistica version 6 (StatSoft Inc., 2004) and Microsoft Excel software. 


\section{$441 \quad$ Results and discussion}

442 The entire dataset associated with stable isotopes analyses is shown in Figure 3a, whereas 443 Figure $3 \mathrm{~b}$ allows a better representation of surface and groundwater data. Figure $3 \mathrm{c}$ 444 presents the average values of groundwater and surface water groups in the same range as 445 Figure $3 \mathrm{~b}$. As a complement, Figure 4 presents boxplots showing the non-outlier range, $44625^{\text {th }}$ and $75^{\text {th }}$ percentiles and median SEC, $\delta^{18} \mathrm{O}$ and ${ }^{3} \mathrm{H}$ values for selected groups of data. 447 The non-outlier range is defined as maximum and minimum values within 1.5 times the 448 interquartile range. It was chosen not to show the data outside of the non-outlier range in 449 the boxplots (Figure 4) in order to allow a better representation of the data. Nevertheless, 450 the entire dataset is shown in Figure 3. Results associated with three of the main 451 components of the water cycle (namely precipitation, surface waters and groundwater) 452 are first discussed separately to address specific topics and jointly interpreted afterward to 453 propose a regional-scale conceptual model of groundwater flow.

Figure 4. $\delta^{18} \mathrm{O}(\mathrm{a} ; \mathrm{b}),{ }^{3} \mathrm{H}$ (c) and SEC (d) boxplots for precipitation, surface waters, springs and groundwater

462 The $\delta^{2} \mathrm{H}$ and $\delta^{18} \mathrm{O}$ values of precipitation ranged from $-217.9 \%$ o to $-29.9 \%$ and $-28.4 \%$ o to $463-4.8 \%$ respectively (Figure 3a). These data are used to define the Local Meteoric Water 464 Line, calculated using precipitation $(n=164)$ and snowpack data $(n=31)\left(L M W L ; \delta^{2} H=\right.$ $4657.84 \delta^{18} \mathrm{O}+9.20 \%\left(\mathrm{n}=195, \mathrm{r}^{2}=0.99\right)$; Figure 3$)$. The LMWL is relatively close to 466 Craig's global meteoric water line (GMWL; $\delta^{2} \mathrm{H}=8 \delta^{18} \mathrm{O}+10 \%$ SMOW; Craig 1961). 467 In terms of temporal variations, the monthly precipitation data revealed the expected 468 temperature-dependant isotopic cycle, with heavy isotopes depletion during the colder 
469 period and enrichment during the warmer period (Figure 5). Such a pattern is typical of 470 boreal regions with summer rains enriched in heavy isotopes and winter precipitation 471 depleted in heavy isotopes in response to strong seasonal variations in temperature (Clark 472 and Fritz 1997). Overall, the temporal variations in the isotopic composition of 473 precipitation reflect the marked seasonality of the study area.

474 The weighted mean annual isotopic compositions of precipitation at stations 1, 3 and 4 475 are shown in Table 5. The data do not show a clear relationship between precipitation $476 \delta^{2} \mathrm{H}-\delta^{18} \mathrm{O}$ and latitude. The absence of a latitudinal gradient in precipitation isotopic 477 composition could reflect the superimposed influence of the three major air masses that 478 supply moisture over the study area, namely (1) the Arctic air mass (from the north), 479 (2) the tropical vapor (from the south) and (3) the westerlies (Bryson 1966; Fritz et al. 480 1987). Given the relatively flat landscape of the study area, the effect of altitude on 481 precipitation $\delta^{2} \mathrm{H}-\delta^{18} \mathrm{O}$ values is probably limited. Finally, evaporation processes might 482 also influence the isotopic composition of precipitation at the local scale, near large water 483 bodies such as the Témiscamingue, Simard and Abitibi lakes (Figure 1). Further data 484 would be required to better explain spatial variations in the isotopic composition of 485 precipitations at the scale of the study area.

486 Samples collected from the snowpack in March 2014 (prior to the onset of spring 487 snowmelt) revealed $\delta^{2} \mathrm{H}$ and $\delta^{18} \mathrm{O}$ values ranging from $-184.4 \%$ o to $-151.6 \%$ and $-24.5 \%$ 488 to $-20.6 \%$ respectively (Figure 3). Ice layers have been found in some places in the 489 snowpack during sample collection. It is recognized that isotopic fractionation occurs 490 during snowmelt (Taylor et al. 2001; Laudon et al. 2002). This suggests that the different 491 layers identified within the sampled snowpack (which reflect melting / refreezing events) 492 are most likely characterized by variable isotopic compositions. Nevertheless, here, the 493 bulk samples (i.e. composite samples of the entire thickness of snow) collected from the 494 snowpack prior to the onset of the snowmelt event plot uniformly on the left side of the 495 LMWL (Figure 3), with values similar to that measured at the precipitation monitoring 496 stations. This suggests that the bulk of the snowpack preserved an isotopic composition 497 that is similar to that of precipitation prior to the onset of the spring snowmelt event. 
498 Overall, the isotopic compositions of samples retrieved from the snowpack do not define 499 a clear latitudinal gradient at the regional scale. sampling stations (2013-2015).

\section{The isotopic composition of surface waters: inflows, evaporative enrichment and mixing}

507 The regional dataset reveals a significant variability in surface waters $\delta^{2} \mathrm{H}$ and $\delta^{18} \mathrm{O}$, with 508 values ranging from $-100.8 \%$ o to $-68.9 \%$ and $-13.7 \%$ o to $-7.6 \%$, respectively (for regional 509 average values of $-80.9 \%\left(\delta^{2} \mathrm{H}\right)$ and $\left.-10.7 \%\left(\delta^{18} \mathrm{O}\right)\right)$. The isotopic composition of surface

510 waters can present both spatial and temporal variations owing to the superimposed 511 influence of precipitation, groundwater inflow, evaporation and tributary mixing 512 processes (Yi et al. 2010). Temporal variations are commonly observed in regions 513 characterized by a marked seasonality where heavy isotope depletion following snowmelt 514 and enrichment caused by evaporation during the ice off period have been reported (e.g. 515 see Telmer and Veizer 2000; Yi et al. 2010). Here, most of the samples were collected in 516 summer (Table 2), and the data plot below the LMWL, consistent with the hypothesis 517 that surface waters have undergone heavy isotope enrichment owing to evaporation. A 518 surface Local Evaporation Line (LEL): $\delta^{2} \mathrm{H}=3.80 \delta^{18} \mathrm{O}-40.22 \%$ o $\left(\mathrm{n}=99, \mathrm{r}^{2}=0.65\right)$

519 (Figure 3a) is evaluated from the data. The evaporation over inflow ratio (E/I), as 520 described by Gibson and Edwards (2002), corresponds to the water balance of a surface 521 water body and relates to the combined effects of evaporative heavy isotope enrichment 522 and dilution by inflowing waters. The E/I ratio is used here for evaluating the 523 hydrological processes responsible for the distribution of surface water data plotting 524 below the LMWL in $\delta^{2} \mathrm{H}$ vs $\delta^{18} \mathrm{O}$ graphs (Figure 3). The Hydrocalculator application 525 from Skrzypek et al. (2015) was used to calculate evaporation over inflow (E/I) ratios 
526 under steady state conditions (shown over the LEL in Figure 6a). This application solves

527 a modified form of the Craig and Gordon (1965) model:

$528 \quad \frac{E}{I}=\left[\frac{\left(\delta_{L}-\delta_{P}\right)}{\left(\delta^{*}-\delta_{L}\right) \times m}\right]$

Equation 2

529 Where $\delta_{L}$ corresponds to the isotopic composition of the sampled surface water, $\delta_{P}$ is the 530 initial isotopic composition of water and $\delta^{*}$ is the limiting isotopic enrichment factor (a 531 function of the isotopic fractionation factor and atmospheric isotopic composition and 532 relative humidity). Similar approaches are used to evaluate the E/I ratios of rivers 533 (e.g.: Telmer and Veizer 2000) and lakes (e.g. Gibson and Edwards 2002). Here, 534 theoretical calculations are proposed for points falling directly on the LEL evaluated from 535 the dataset, the latter corresponding to the $\delta_{L}$ term of equation 2. The initial isotopic 536 composition of water $\left(\delta_{P}\right)$ is assumed to correspond to the intersection between the 537 LMWL and the LEL. The isotopic composition of atmospheric moisture $\left(\delta_{A}\right)$, which is 538 needed to evaluate $\delta^{*}$ in equation 2 , is evaluated according to three scenarios:

1- $\delta_{A}$ is in equilibrium with the flux weighted average isotopic composition of precipitation between the months of May and August $\left(\delta_{A}=-141.21 \% ;-19.45\right.$ $\%$ );

2- $\delta_{A}$ is in equilibrium with the arithmetic average isotopic composition of precipitation between the months of May and August $\left(\delta_{A}=-137.42 \%\right.$; -18.91 $\%$ );

546 A temperature of $22{ }^{\circ} \mathrm{C}$ and a relative humidity of $70 \%$ are assumed, consistent with the

547 conditions encountered during the warm ice off period within the study region. The 548 isotope fractionation factors are calculated from the Horita and Wesolowski (1994) 549 equations.

550 Depending on the model parameters used, E/I ratios ranging between $0 \%$ and $36 \%$ are 551 evaluated from the regional dataset (Figure 6a). Based on this theoretical framework, 552 surface water samples plotting closer to the LMWL most likely present the lowest E/I 
553 ratios. These surface waters might be affected by significant evaporation losses, but 554 inflows (mostly precipitation and groundwater, both plotting along the LMWL) are 555 sufficient to buffer the heavy isotope enrichment resulting from evaporation. On the 556 contrary, the samples that are most enriched in heavy isotopes (i.e. plotting further along 557 the right side of the LEL) most likely present the highest E/I ratios. Within the regional 558 hydrogeological framework, it is most likely that evaporation mainly occurs within lakes 559 and stagnant water bodies whereas dynamic in stream processes mainly reflect surface 560 water / groundwater interactions and tributary mixing.

561 One distinctive feature of the regional dataset is that most of the kettle lakes plot on the 562 right side of the LEL, suggesting overall high E/I ratios in comparison to other surface 563 waters (Figure 6b). Recent studies by Isokangas et al. (2015) and Arnoux et al. (2017) 564 provided novel methods to estimate the groundwater dependency of such lakes based on $565 \mathrm{E} / \mathrm{I}$ ratios calculated from stable isotope data, among other. Here, quantifying the 566 groundwater dependency of lakes is precluded by uncertainties related to volumes, 567 surface water inflows and potential heterogeneities caused by thermal stratification and 568 temporal variations. Nevertheless, the distinctive isotopic composition of kettle lakes 569 stresses the need for conducting further studies aimed at quantifying their water balance 570 to better anticipate their sensitivity to climate change and human pressure.

574 The isotopic composition of groundwater and springs: recharge, discharge, mixing and regional 575 flowpaths

576 The stable isotopes analyses $\left(\delta^{2} \mathrm{H}-\delta^{18} \mathrm{O}\right)$ conducted on 351 groundwater and springs 577 samples are shown on the graphs of Figures 3, 4a and 4b. The data associated with 578 groundwater samples are represented according to the four main types of regional 579 aquifers, as shown in Figure 2 (unconfined granular aquifers; unconfined fractured rock 580 aquifers; confined granular aquifers; confined fractured rock aquifers). The $\delta^{2} \mathrm{H}$ and $\delta^{18} \mathrm{O}$ 581 values of groundwater samples ranged from $-107.8 \%$ to $-71.9 \%$ and $-15.2 \%$ o to $-9.4 \%$, 
582 respectively, for a regional average of $-13.3 \%\left(\delta^{18} \mathrm{O}\right)$; $-93.4 \%$ o $\left(\delta^{2} \mathrm{H}\right)$. The $\delta^{2} \mathrm{H}$ and $\delta^{18} \mathrm{O}$ 583 values of spring samples ranged from $-106.3 \%$ to $-75.1 \%$ and $-14.4 \%$ o to $-9.7 \%$, 584 respectively for a regional average of $-13.8 \%$ o $\left(\delta^{18} \mathrm{O}\right)$; $-98.1 \%$ o $\left(\delta^{2} \mathrm{H}\right)$. Previous work by 585 Castelli (2012) revealed that the isotopic composition of springs is fairly stable 586 (1) throughout the ice-off season and (2) from year to year. Similarly, it is assumed here 587 that the isotopic composition of groundwater is relatively constant in time. The focus is 588 therefore set on spatial rather than temporal variations in isotopic compositions. The data 589 associated with groundwater and springs are evenly distributed around the LMWL. This 590 suggests that (1) infiltration and recharge processes are not significantly affected by 591 evaporation losses and (2) aquifers are not significantly affected by inflows from 592 evaporated surface waters. This is consistent with the regional hydrogeological 593 framework because: (1) the main recharge areas consist of coarse grained glaciofluvial 594 formations where high infiltration rates prevent surface pounding (and associated 595 evaporation) and (2) physical measurements suggest that groundwater generally 596 discharges into surface waters at the regional scale (Cloutier et al. 2013; 2015). Although 597 water losses by plant transpiration prior to groundwater recharge might be significant, the 598 available dataset does not allow the quantification of this process. Results also support 599 the hypothesis that regional surface waters - groundwater interactions are essentially 600 restricted to groundwater discharging into surface waters, and not the inverse (otherwise, 601 some groundwater samples would most likely be plotting significantly below the LMWL 602 owing to mixing with evaporated surface waters). The data do not show systematic 603 latitudinal trends in the stable isotope composition of groundwater at the regional scale. 604 This is most likely caused by the complex mixing of recharge originating from the main 605 atmospheric air masses supplying precipitation over the study region.

606 The data associated with the four main types of aquifers present a significant dispersion 607 and overlap within Figures 3 and 4b. Nevertheless, two main observations arise from the 608 distribution of data within the $\delta^{2} \mathrm{H}-\delta^{18} \mathrm{O}$ plots:

609 (1) The data associated with unconfined granular aquifers present a greater 610 dispersion in comparison to the other types of aquifers (Figure 4b); 
(2) Confined granular aquifers and fractured rock aquifers (both confined and unconfined) tend to plot further on the right side of LMWL in comparison to springs and unconfined granular aquifers (Figure 3c).

These observations are interpreted in an effort to further constrain the understanding of regional flowpaths within the hydrogeological environment conceptually represented in Figure 2. The unconfined granular aquifers represent the main regional recharge zones where rain and melted snow preferentially infiltrate at different periods of the year, depending on local climatic and hydrological conditions (Cloutier et al. 2016). The proposed interpretation of groundwater stable isotope data is that unconfined granular aquifers present a greater $\delta^{2} \mathrm{H}-\delta^{18} \mathrm{O}$ variability owing to a shorter residence time of water within shallow and dynamic systems such as eskers and moraines. The results associated with ${ }^{3} \mathrm{H}$ analyzes (Figure 4c) further support this interpretation. Overall, the tritium data suggest that water samples from springs, unconfined granular aquifers and unconfined fractured rock aquifers correspond to modern waters (with values ranging between approximately 9 and $17 \mathrm{TU}$, consistent with the subdivisions proposed by Clark and Fritz 1997). Such results suggest a relatively short residence time of water in these shallow components. In contrast, samples collected within confined aquifers (both granular and fractured) present tritium contents below $0.8 \mathrm{TU}$ (consistent with submodern values according to the subdivisions proposed by Clark and Fritz 1997). Such results suggest that within the region, confined aquifers generally contain older groundwater in comparison to unconfined aquifers.

The sampled springs are all located on the flanks of unconfined granular aquifers associated with glaciofluvial formations (eskers / moraines). Their heavy isotope depletion (Figure 3c) with respect to most groundwater samples suggests that superficial flow systems associated with springs are submitted to a greater influence of lighter precipitation. As previously discussed, within the study area, precipitations depict a clear seasonal pattern, with lighter values recorded during the cold period (Figure 5). Under such conditions, one likely explanation is that a significant proportion of the groundwater recharge associated with snowmelt contributes to springs discharge. This stands as a plausible explanation because the springs located on the flanks of eskers and moraines 
641 essentially consist in «overflows» allowing groundwater to discharge from unconfined 642 granular aquifers towards the surface water network. From a physical perspective, it 643 seems likely that «overflow» conditions would be favored following the thawing period, 644 as groundwater levels are generally raising within the eskers and moraines of the region 645 during this period (Cloutier et al. 2013; 2015). During the dryer summer period, recharge 646 rates are likely reduced, therefore limiting the supply of heavier water associated with 647 summer precipitation to shallow flow systems. In fall, at the end of the warmer period, 648 when the uptake of water by vegetation is reduced and precipitation are increased, 649 recharge rates most likely increase, further supplying water that is depleted in heavy 650 isotopes to the shallow flow systems associated with springs. The loss of lighter isotopes 651 resulting from groundwater discharge within springs could also partly explain why the 652 confined aquifers, located further downstream within the flow systems, are slightly 653 enriched in heavy isotopes with respect to springs and shallow unconfined aquifers 654 (Figures 3c; 4b). One key regional observation discussed by Cloutier et al. (2016) is that 655 extensive peatlands are developed on the flanks of several eskers and moraines of the 656 region. The contacts between esker/moraines and these extensive peatlands are 657 interpreted as diffuse groundwater seepage zones (Nadeau et al. 2015). The process 658 related to the loss of lighter isotopes within punctual springs might therefore be 659 generalized to most of the unconfined aquifers associated with extensive peatlands and 660 diffuse groundwater seepage zones. In addition, it seems most likely that the areas 661 associated with unconfined fractured rock aquifers are less prone to groundwater 662 recharge during snowmelt in comparison to the areas associated with glaciofluvial 663 formations (i.e. unconfined granular aquifers). This hypothesis is based on the contrast in 664 hydraulic conductivity $(\mathrm{K})$ between the fractured bedrock (lower $\mathrm{K}$ ) and the eskers and 665 moraines (higher K) (e.g. see Cloutier et al. 2015). The differences in the isotopic 666 composition of unconfined granular aquifers and springs compared to that of confined 667 granular aquifers and fractured rock aquifers (both confined and unconfined) could 668 therefore reflect the relative contribution of snowmelt induced recharge for the different 669 types of aquifers.

670 The interpretations discussed above are further illustrated in Figure 7a, where the SEC of 671 springs and groundwater is plotted against the corresponding $\delta^{18} \mathrm{O}$ values. The data 
672 presented therein reveals that confined fractured rock aquifers generally present the 673 highest SEC values whereas the unconfined granular aquifers present the lowest SEC 674 values. This is also depicted in Figure 4d where a gradual increase in SEC is observed 675 from unconfined towards confined aquifers. SEC can thus be used as a proxy for 676 groundwater residence time and geochemical evolution, higher SEC generally implying 677 more evolved groundwater. This pattern most likely reflects the combined effects of 678 (1) increased geochemical interactions between groundwater and the geological 679 environment along regional flowpaths and (2) recharge of precipitation having very low 680 dissolved solid concentration (thus quite low SEC) in unconfined granular aquifers areas. 681 The mixing model shown in Figure 7a further supports the interpretations proposed 682 above. Three end-members are proposed to explain the variability in both $\delta^{18} \mathrm{O}$ and SEC 683 values:

1- End-member «A» presents low SEC and $\delta^{18} \mathrm{O}$, it is identified as representative of recent snowmelt induced recharge. The lowest non-outlier $\delta^{18} \mathrm{O}$ value recorded in unconfined granular aquifers (lower end of the boxplot shown in Figure 4b) is used to characterize this end-member, whereas the SEC value is set to 0.05 $\mathrm{mS} / \mathrm{cm}$, corresponding to the lowest non-outlier SEC value recorded in unconfined granular aquifers (lower end of the boxplot shown in Figure 4d);

2- End-member «B» presents low SEC and high $\delta^{18} \mathrm{O}$ close to $-12 \%$, it is identified as representative of fall recharge affected by relatively high temperature rain. The highest non-outlier $\delta^{18} \mathrm{O}$ value recorded in unconfined granular aquifers (higher end of the boxplot shown in Figure 4b) is used to characterize this end-member, whereas the SEC value is set to $0.05 \mathrm{mS} / \mathrm{cm}$, as previously defined for endmember «A»;

3- End-member $« \mathrm{C} »$ presents high SEC and $\delta^{18} \mathrm{O}$, it is identified as representative of well mixed water (from various recharge zones or various recharge periods) that is geochemically evolved owing to prolonged water-rock interactions along flowpaths, thus leading to a higher SEC. The median $\delta^{18} \mathrm{O}$ isotopic composition of confined fractured rock aquifers is used to constrain this end-member, and the SEC is set to $1.8 \mathrm{mS} / \mathrm{cm}$ (the highest recorded value in the dataset, Figure $4 \mathrm{~d}$ ). 
702 The dashed lines in figure $7 \mathrm{a}$ and $\mathrm{b}$ represent mixing lines between the three end703 members, at 25\% intervals. In this mixing model, the SEC is considered linearly related

704 to the geochemical level of evolution of groundwater, which is most probably not linearly 705 related to the groundwater residence time.

706 Six main outliers are identified among the groundwater/springs dataset in Figures $3 b$. 707 These six points plot below the LMWL in Figure 3, suggesting an evaporative 708 enrichment that is not observed in the other groundwater samples. Five of these points are 709 associated with samples collected in the immediate vicinity of lakes whereas the fifth one 710 was collected within a mining site. It is proposed that the five samples collected near 711 lakes and presenting heavy isotope enrichment and low SEC values are directly affected 712 by the supply of evaporated and low SEC lake waters. The wells characterized by low 713 SEC and low $\delta^{18} \mathrm{O}$ values are likely affected by nearby snowmelt induced groundwater

714 recharge, whereas those with low SEC and significantly higher $\delta^{18} \mathrm{O}$ values are likely 715 affected by mixing with surface waters. In that sense, within the study region, stable 716 isotope data could be used as a screening tool to detect groundwater wells that are 717 affected by surface waters. Such wells would deserve a specific attention in groundwater 718 monitoring programs because they might be more vulnerable to microbial contamination 719 originating from surface waters. Finally, the sixth outlier point was collected in a 720 groundwater well located within a mining site; its isotopic composition and SEC value 721 most likely reflect anthropogenic effects.

Figure 7. Specific electrical conductivity (SEC) vs $\delta^{18} \mathrm{O}$ of springs, surface waters

\section{Local and regional systems of groundwater flow: insights from water stable isotopes}

727 Tóth (1963) proposed a conceptual model of groundwater flow in 2D cross sections 728 involving local, intermediate and regional groundwater flow sub-systems. Such 729 conceptual models constitute a central unifying concept to describe groundwater 
730 recharge, flow and discharge processes at various scales and provide a framework that is 731 of upmost importance to interpret regional hydrogeochemical datasets. Tóth (1999) 732 further developed his conceptual model by presenting groundwater as a geologic agent 733 interacting with the environment and inheriting a geochemical composition that preserves 734 an archive of hydrogeochemical processes and systematically evolves along flow paths. 735 Following Toth's pioneer work, the different flow systems of the study area are 736 interpreted with a focus on the isotopes of the water molecule itself, rather than other 737 dissolved species. The working hypothesis is that within the considered spatiotemporal 738 domain, the isotopic composition $\left(\delta^{2} \mathrm{H}-\delta^{18} \mathrm{O}\right)$ of water is not significantly affected by 739 water-rock interactions but rather mainly reflects the superimposed effects of 740 precipitation isotopic composition, evaporation, recharge, mixing and discharge 741 processes that vary in time and space. The average $\delta^{2} \mathrm{H}-\delta^{18} \mathrm{O}$ compositions of 742 precipitation (including snow samples), surface waters, springs and groundwater are 743 shown in Figure 8, which consists in a more detailed representation of the regional 744 hydrogeological conditions that was initially conceptualized in Figure 2.

745 The conceptual model illustrates precipitation showing the greatest isotopic variability 746 and recharge occurring mainly within shallow unconfined aquifers, where the variability 747 in the isotopic composition of water is attenuated with respect to precipitation due to 748 mixing. Part of the water flowing within these unconfined aquifers discharges towards 749 surface waters through springs and diffuse seepage zones that are generally depleted in 750 heavy isotopes with respect to the average composition of groundwater. Surface waters 751 are subsequently submitted to evaporation (causing heavy isotope enrichments) and to 752 further dilution by precipitation and groundwater discharge. The remaining groundwater 753 flows from unconfined recharge areas towards confined aquifers, allowing two key 754 geochemical processes to occur along flow paths:

755 (1) Water rock interaction: groundwater becomes increasingly concentrated in 756 dissolved ions owing to prolonged water-rock interactions, as shown by the 757 gradual increase in SEC among the various hydrological components, from 758 precipitations towards confined fractured rock aquifers (Figure 4d). This 759 interpretation is further supported by the tritium analyses (Figure 4c), which 
suggest that confined aquifers are characterized by longer water residence times compared to springs and unconfined aquifers;

(2) Mixing: The isotopic composition of groundwater evolves towards a regional average owing to the mixing of water originating from various recharge zones or various recharge periods. This is illustrated in Figure $4 \mathrm{~b}$ and Figure $7 \mathrm{a}$, which suggest that mixing processes tend to damp the variability recorded in $\delta^{18} \mathrm{O}$ values within confined aquifers. In other terms, the greater the proportion of unconfined aquifers in the vicinity on a given site, the greater the potential variability in the stable isotope composition of groundwater.

769 Clark and Fritz (1997) proposed a schematic representation of the attenuation of seasonal 770 isotope variations in recharge waters within the unsaturated zone. These authors reported 771 that temporal isotopic variations around an average value are gradually damped with 772 increasing depth as a function of flowpaths lengths and residence times. A comparable 773 interpretation is proposed here to explain the evolution of groundwater SEC and $774 \delta^{2} \mathrm{H}-\delta^{18} \mathrm{O}$ along local, intermediate and regional flow systems (Figures 7 and 8). On one 775 hand, since recharge processes are primarily associated with sectors of unconfined 776 aquifers and partly controlled by hydrogeological conditions that are highly 777 heterogeneous at the regional scale, a significant variability is recorded in unconfined 778 aquifers isotopic compositions. Overall, the unconfined granular aquifers associated with 779 coarse grained glaciofluvial formations (eskers and moraines) are more prone to recharge 780 during snowmelt and therefore present low $\delta^{2} \mathrm{H}-\delta^{18} \mathrm{O}$ values in comparison to the other 781 types of aquifers. Similarly, the springs found on the flanks of eskers and moraines are 782 depleted in heavy isotopes. On the other hand, recharge areas associated with unconfined 783 bedrock aquifers are more prone to runoff generation during the intense snowmelt event, 784 and are therefore generally enriched in heavy isotopes in comparison to unconfined 785 granular aquifers. Finally, the confined aquifers located further along groundwater 786 flowpaths are fed by numerous interconnected unconfined aquifer areas that are 787 heterogeneously distributed over the region. The result of the mixing processes occurring 788 along flowpaths is a gradual evolution towards a regional average value within confined 789 aquifers. Based on this interpretation, groundwater samples from confined aquifers that 
790 present an isotopic composition that significantly differs from the regional average most

791 likely represents sites where the preferential influence of a nearby recharge area are 792 recorded.

Figure 8. Isotopic variations within local, intermediate and regional flow systems

\section{Conclusions}

The isotopic composition of water $\left(\delta^{2} \mathrm{H}-\delta^{18} \mathrm{O}\right.$ and $\left.{ }^{3} \mathrm{H}\right)$ in precipitation, surface waters, groundwater and springs was used to improve the understanding of regional flow systems in the southern portion of the Barlow-Ojibway Clay Belt. The data allowed the identification of the key hydrological processes driving spatiotemporal isotopic variations and deciphering the interaction pathways between the various components of the water cycle, from atmospheric moisture to groundwater discharge:

(1) Regional precipitations depict a clear seasonal pattern with heavy isotope depletion recorded in winter and heavy isotope enrichment in summer. The data did not reveal clear spatial trends in precipitation $\delta^{2} \mathrm{H}-\delta^{18} \mathrm{O}$, most likely in response to the complex mixing of inputs from the main air masses supplying moisture to the study region. Overall, precipitation data allowed the definition of the local meteoric water line (LMWL: $\delta^{2} \mathrm{H}=7.84 \delta^{18} \mathrm{O}+9.20 \%$; $\left.\mathrm{n}=164 ; \mathrm{r}^{2}=0.99\right)$;

(2) Surface waters plot below the LMWL in a $\delta^{2} \mathrm{H}-\delta^{18} \mathrm{O}$ graph owing to evaporation losses. Calculations conducted using a modified form of the Craig and Gordon (1965) model with the Hydrocalculator application (Skrzypek et al. 2015) provided an estimation of evaporation over inflow (E/I) ratios ranging between $0 \%$ and $36 \%$ at the regional scale;

(3) Groundwater samples plot on the LMWL and are evenly distributed around the average isotopic composition of precipitation in a $\delta^{2} \mathrm{H}-\delta^{18} \mathrm{O}$ graph, suggesting that evaporation processes do not significantly affect regional recharge waters. The $\delta^{2} \mathrm{H}-\delta^{18} \mathrm{O}$ of groundwater in shallow unconfined aquifers presents a greater variability in comparison to confined aquifers owing to mixing processes that tend to buffer the isotopic variability 
818 along the regional groundwater flow paths. This buffering on the isotopic composition variability is accompanied by increasing values of the SEC of groundwater from unconfined to confined aquifers, most likely in response to increasing water-rock interaction timescales, consistent with generally lower tritium contents in confined aquifers;

(4) Unconfined granular aquifers and associated springs are generally slightly depleted in heavy isotopes in comparison to other groundwater samples, suggesting that these shallow flow systems are preferentially recharged during spring snowmelt within the region.

825 Overall, the observations and interpretations of this study support an improvement of a conceptual

826 hydrogeological model of local and regional hydrological systems and flow paths that is consistent

827 with the geological framework. This conceptual model illustrates how water isotopes can be used to

828 constrain physically-based interpretations of local, intermediate and regional flow systems such as

829 those inspired by the pioneering work of Tóth (1963), even in a highly heterogeneous region.

830 The buffering of isotopic variability in groundwater from groundwater recharge areas

831 located in unconfined aquifers towards groundwater discharge areas and confined

832 aquifers located further along regional flow paths provides a framework for deciphering

833 the processes associated with the geochemical evolution of groundwater, as a

834 complement to understandings based on dissolved major ions and trace elements. 


\section{Acknowledgements}

837 The authors would like to acknowledge the financial contribution of the Quebec Ministry 838 of the Environment (Ministère du Développement durable, de l'Environnement et de la

839 Lutte contre les changements climatiques) through the Programme d'Acquisition des

840 Connaissances sur les Eaux souterraines (PACES). We also acknowledge the financial 841 contribution of regional partners involved in the PACES program, including the Regional 842 County Municipalities (Abitibi, Vallée-de-l'Or, Abitibi-Ouest, Ville de Rouyn-Noranda, 843 Témiscamingue) and the Regional Conference of Elected Officials of Abitibi844 Témiscamingue. The authors acknowledge the Fondation of the University of Quebec in 845 Abitibi-Temiscamingue (FUQAT) for scholarships to the project of Nathalie Rey. We 846 thank Magalie Roy for geomatics support. The work of students involved in the project as 847 field assistants, and the collaboration of the population of Abitibi-Temiscamingue giving 848 site access are greatly appreciated. The authors kindly thank two anonymous reviewers 849 for constructive comments that greatly contributed to improve the original manuscript. 


\section{References}

852 Araguás-Araguás, L., K. Froehlich, and K. Rozanski. 2000. Deuterium and oxygen-18 isotope composition of precipitation and atmospheric moisture. Hydrological Processes 14(8): 1341-1355.

Arnoux, M., F. Barbecot, E. Gibert-Brunet, J. Gibson, E. Rosa, A. Noret, and G. Monvoisin. 2017. Geochemical and isotopic mass balances of kettle lakes in southern Quebec (Canada) as tools to document variations in groundwater quantity and quality. Environmental Earth Sciences 76(3): 106.

Asselin, M. 1995. L'Abitibi-Témiscamingue: trois sous-régions, une région. Chap. 1 in Histoire de l'Abitibi-Témiscamingue (sous la direction de Odette Vincent), ed. Institut québécois de recherche sur la culture, 21-65. Québec, Canada.

Birks, S.J., and J.J. Gibson. 2009. Isotope Hydrology Research in Canada, 2003-2007. Canadian Water Resources Journal 34(2): 163-176.

Bryson, R.A. 1966. Air masses, streamlines and the boreal forest. Geographical Bulletin 8(3): 228-269.

Bryson, R.A., and F.K. Hare. 1974. The Climates of North America. Chap. 1 in Climates of North America, in World Survey of Climatology 2 vols, ed. R.A. Bryson, and F.K. Hare, 1-47. Amsterdam-London-New York: Elsevier Publishers.

Castelli, S. 2012. Hydrogéochimie des sources associées aux eskers de l'Abitibi, Québec. Maîtrise, Département des génies civil, géologique et des mines, école polytechnique de Montréal, Université de Montréal, 126 pp.

Clark, I. D. and Fritz, P., 1997. Environmental Isotopes in Hydrogeology. CRC Press, Boca Raton (London), New York, 328 pp.

Cloutier, V., D. Blanchette, P.-L. Dallaire, S. Nadeau, E. Rosa, and M. Roy. 2013. Projet d'acquisition de connaissances sur les eaux souterraines de l'Abitibi-Témiscamingue (partie 1). Rapport final. Groupe de recherche sur l'eau souterraine. Institut de 

recherche en mines et en environnement. Université du Québec en AbitibiTémiscamingue, $151 \mathrm{pp}$.

879 Cloutier, V., D. Blanchette, P.-L. Dallaire, S. Nadeau, E. Rosa, and M. Roy. 2015. Projet d'acquisition de connaissances sur les eaux souterraines de l'AbitibiTémiscamingue (partie 2). Rapport final. Groupe de recherche sur l'eau souterraine,

Cloutier, V., E. Rosa, M. Roy, S. Nadeau, D. Blanchette, P.-L. Dallaire, G. Derrien, and Institut de recherche en mines et en environnement, Université du Québec en Abitibi-Témiscamingue, 313 pp.

Collini, M., L. Germain, and J. Thibeault. 2007. Portrait des ressources hydriques. Observatoire de l'Abitibi-Témiscamingue. Les portraits de la région, $47 \mathrm{pp}$.

889 Coplen, T.B. 1996. New guidelines for reporting stable hydrogen, carbon, and oxygen isotope-ratio data. Geochimica et Cosmochimica Acta 60(17): 3359-3360.

Craig, H. 1961. Isotopic variations in meteoric waters. Science 133(3465): 1702-1703.

Craig, H., and L.I. Gordon. 1965. Deuterium and oxygen 18 variations in the ocean and marine atmosphere. In Stable Isotopes in Oceanographic Studies and Paleotemperatures, 1965, Spoleto, Italy, ed. E. Tongiorgi, 9-130. Laboratorio di Geologia Nucleare: Pisa.

897 Ferguson, P.R., N. Weinrauch, L.I. Wassenaar, B. Mayer, and J. Veizer. 2007. Isotope constraints on water, carbon, and heat fluxes from the northern Great Plains region of North America. Global biogeochemical cycles 21(2).

900 Fritz, P., R. Drimmie, S. Frape, and K. O'shea. 1987. The isotopic composition of 901 precipitation and groundwater in Canada. In Isotope techniques in water resources 
902

903

904

905

906

907

908

909

910

911

912

913

914

915

916

917

918

919

920

921

922

923

924

925

926

927

development. Proceedings of a symposium, 30 March - 3 April 1987. International Atomic Energy Agency: Vienna, Austria.

Gat, J.R. 1996. Oxygen and hydrogen isotopes in the hydrologic cycle. Annual Review of Earth and Planetary Sciences 24(1): 225-262.

Gat, J.R., C.J. Bowser, and C. Kendall. 1994. The contribution of evaporation from the Great Lakes to the continental atmosphere: estimate based on stable isotope data. Geophysical Research Letters 21(7): 557-560.

Gibson, J.J., and T.W.D. Edwards. 2002. Regional water balance trends and evaporationtranspiration partitioning from a stable isotope survey of lakes in northern Canada. Global Biogeochemical Cycles 16(2): 10-1-10-14.

Gibson, J.J., T.W.D. Edwards, S.J. Birks, N.A. St Amour, W.M. Buhay, P. McEachern, B.B. Wolfe, and D.L. Peters. 2005. Progress in isotope tracer hydrology in Canada. Hydrological Processes 19(1): 303-327.

Green, T.R., M. Taniguchi, H. Kooi, J.J. Gurdak, D.M. Allen, K.M. Hiscock, H. Treidel, and A. Aureli. 2011. Beneath the surface of global change: Impacts of climate change on groundwater. Journal of Hydrology 405(3-4): 532-560.

Hare, F.K., and J.E. Hay. 1974. The Climate of Canada and Alaska. Chap. 2 in Climates of North America, in World Survey of Climatology 11 vols, ed. R.A. Bryson, and F.K. Hare, 49-192. Amsterdam-London-New York: Elsevier Publishers.

Horita, J., and D.J. Wesolowski. 1994. Liquid-vapor fractionation of oxygen and hydrogen isotopes of water from the freezing to the critical temperature. Geochimica et Cosmochimica Acta 58(16): 3425-3437.

Isokangas, E., K. Rozanski, P.M. Rossi, A.K. Ronkanen, and B. Kløve. 2015. Quantifying groundwater dependence of a sub-polar lake cluster in Finland using an isotope mass balance approach. Hydrology and Earth System Sciences 19(3): 1247-1262. 
928 Jeelani, G., U. Saravana Kumar, and B. Kumar. 2013. Variation of $\delta 18 \mathrm{O}$ and $\delta \mathrm{D}$ in 929 precipitation and stream waters across the Kashmir Himalaya (India) to distinguish 930 and estimate the seasonal sources of stream flow. Journal of Hydrology 481: 157$931 \quad 165$.

932 Kebede, S., Y. Travi, and K. Rozanski. 2009. The $\delta 18 \mathrm{O}$ and $\delta 2 \mathrm{H}$ enrichment of Ethiopian 933 lakes. Journal of Hydrology 365(3-4): 173-182.

934 Kortelainen, N.M., and J.A. Karhu. 2004. Regional and seasonal trends in the oxygen and 935 hydrogen isotope ratios of Finnish groundwaters: a key for mean annual 936 precipitation. Journal of Hydrology 285(1-4): 143-157.

937 Laudon, H., H.F. Hemond, R. Krouse, and K.H. Bishop. 2002. Oxygen 18 fractionation 938 during snowmelt: Implications for spring flood hydrograph separation. Water 939 Resources Research 38(11): 40-1-40-10.

940 MAMROT (Ministère des Affaires municipales et de l'Occupation du territoire, 941 Gouvernement du Québec). 2016. Répertoire des municipalités, Abitibi$942 \quad$ Témiscamingue, Québec. http://www.mamrot.gouv.qc.ca/repertoire-des943 municipalites/fiche/region/08/ (accessed May 2016).

944 MRNF (Ministère des Ressources naturelles et de la Faune). 2006. Portrait Territorial 945 Abitibi-Témiscamingue, 88 pp.

946 Nadeau, S., E. Rosa, and V. Cloutier. 2017. Accepted: Article ID : TCWR 1354722. 947 Stratigraphic sequences map for groundwater assessment and protection of 948 unconsolidated aquifers: A case example in the Abitibi-Témiscamingue region, 949 Québec, Canada. Canadian Water Resources Journal.

950 Nadeau, S., E. Rosa, V. Cloutier, R.-A. Daigneault, and J. Veillette. 2015. A GIS-based 951 approach for supporting groundwater protection in eskers: Application to sand and 952 gravel extraction activities in Abitibi-Témiscamingue, Quebec, Canada. Part B. 953 Journal of Hydrology: Regional Studies 4: 535-549. 
954 Paradis, S.J. 2005. Géologie des formations en surface et histoire glaciaire, Lac 955 Castagnier, Québec. Geological Survey of Canada, Map 1991A, scale 1:100,000.

956 Paradis, S.J. 2007. Géologie des formations en surface et histoire glaciaire, Lac Blouin, 957 Québec. Geological Survey of Canada, Map 2017A, scale 1:100,000.

958 Poirier, C., T. Fortier-Filion, R. Turcotte, and P. Lacombe. 2012. Apports verticaux 959 journaliers estimés de 1900 à 2010, version 2012. Contribution au Programme d'acquisition de connaissances sur les eaux souterraines. Centre d'expertise hydrique du Québec (CEHQ), Ministère du Développement durable, de

Praamsma, T., K. Novakowski, K. Kyser, and K. Hall. 2009. Using stable isotopes and 965 hydraulic head data to investigate groundwater recharge and discharge in a

Rouleau, A., J. Guha, G. Archambault, and A. Benlahcen. 1999. Aperçu de 1'hydrogéologie en socle précambrien au Québec et des problématiques minières. Hydrogéologie 4: 23-31.

970 Rozanski, K., L. Araguàs-Araguàs, and R. Gonfiantini. 1993. Isotopic patterns in modern global precipitation. Climate Change in Continental Isotopic Records 78: 1-36.

972 Siegel, D., and R. Mandle. 1984. Isotopic evidence for glacial meltwater recharge to the Cambrian-Ordovician aquifer, north-central United States. Quaternary Research 22(3): $328-335$. 2015. Estimation of evaporative loss based on the stable isotope composition of water using Hydrocalculator. Journal of Hydrology 523, 781-789.

978 StatSoft, Inc. 2004. STATISTICA (Data Analysis software System), Version 6. 979 www.statsoft.com. 
980 Taylor, R.G., B. Scanlon, P. Döll, M. Rodell, R. Van Beek, Y. Wada, L. Longuevergne, 981 M. Leblanc, J.S. Famiglietti, and M. Edmunds. 2013. Ground water and climate

983

984

985

986

987

988

989

990

991

992

993

994

995

996

997

998

1000

1001

1002

1003

1004

1005 change. Nature Climate Change 3(4): 322-329.

Taylor, S., X. Feng, J.W. Kirchner, R. Osterhuber, B. Klaue, and C.E. Renshaw. 2001. Isotopic evolution of a seasonal snowpack and its melt. Water Resources Research 37( 3): 759-769.

Telmer, K. and J. Veizer. 2000. Isotopic constraints on the transpiration, evaporation, energy, and gross primary production Budgets of a large boreal watershed: Ottawa River Basin, Canada. Global Biogeochemical Cycles 14(1): 149-165.

Thibaudeau, P., and J.J. Veillette. 2005. Géologie des formations en surface et histoire glaciaire, Lac Chicobi, Québec. Geological Survey of Canada, Map 1996A, scale $1: 100,000$.

Thornthwait, C.W. 1944. Report of committee on transpiration and evaporation. Am. Gephys. Union Trans. Part 5 : 686-693.

Tóth, J. 1963. A theoretical analysis of groundwater flow in small drainage basins. Journal of geophysical research 68(16): 4795-4812.

Tóth, J. 1999. Groundwater as a geologic agent: An overview of the causes, processes, and manifestations. Hydrogeology Journal 7(1): 1-14.

Veillette, J., A. Maqsoud, H. De Corta, and D. Bois. 2004. Hydrogéologie des eskers de la MRC d'Abitibi, Québec. In Proceedings 57th Canadian Geotechnical Conference, 5th Joint CGS/IAH-CNC Conference. Québec city, Canada, October 24-27, 2004, pp. 6-13.

Veillette, J.J. 1986. Surficial geology, New Liskeard, Ontario-Quebec. Geological Survey of Canada, Map 1639A, scale 1:100,000.

Veillette, J.J. 1987a. Surficial geology, Grand Lake Victoria North, Quebec. Geological Survey of Canada, Map 1641A, scale 1:100,000.

CWRJ 28230116_File000000_642833130.dokx 
1006 Veillette, J.J. 1987b. Surficial geology, Lac Simard, Quebec. Geological Survey of 1007 Canada, Map 1640A, scale 1:100,000.

1008 Vörösmarty, C.J., P. Green, J. Salisbury, and R.B. Lammers. 2000. Global water 1009 resources: vulnerability from climate change and population growth. Science $1010 \quad 289(5477): 284-288$.

1011 Wassenaar, L.I., P. Athanasopoulos, and M.J. Hendry. 2011. Isotope hydrology of 1012 precipitation, surface and ground waters in the Okanagan Valley, British Columbia, 1013 Canada. Journal of Hydrology 411(1-2): 37-48.

1014 WHO (World Health Organisation). 2017. Drinking water. 1015 http://www.who.int/mediacentre/factsheets/fs391/en/ (updated July 2017).

1016 Wolfe, B.B., T.L. Karst-Riddoch, R.I. Hall, T.W. Edwards, M.C. English, R. Palmini, S. 1017 McGowan, P.R. Leavitt, and S.R. Vardy. 2007. Classification of hydrological 1018 regimes of northern floodplain basins (Peace-Athabasca Delta, Canada) from 1019 analysis of stable isotopes $(\delta 18 \mathrm{O}, \delta 2 \mathrm{H})$ and water chemistry. Hydrological $1020 \quad$ Processes 21(2): 151-168.

1021 World Water Assessment Programme (WWAP). 2009. The United Nations World Water 1022 Development Report 3 : water in a changing world. Paris: UNESCO.

1023 Yi, Y., J.J. Gibson, J.-F. Hélie, and T.A. Dick. 2010. Synoptic and time-series stable 1024 isotope surveys of the Mackenzie River from Great Slave Lake to the Arctic Ocean, 1025 2003 to 2006. Journal of Hydrology 383(3): 223-232. 


\begin{tabular}{|c|c|c|c|}
\hline Domains & $\begin{array}{l}\text { Hydrological } \\
\text { components }\end{array}$ & $\begin{array}{l}\text { Geological } \\
\text { units }\end{array}$ & $\begin{array}{c}\text { Hydrogeological units and } \\
\text { aquifers }\end{array}$ \\
\hline Atmosphere & $\begin{array}{l}\text { (1) Precipitation } \\
\text { (rain \& snow) }\end{array}$ & - & - \\
\hline Surface & $\begin{array}{l}\text { (2) Snowpack } \\
\text { (3) Surface water } \\
\text { (4) Spring } \\
\end{array}$ & - & - \\
\hline \multirow{5}{*}{\multicolumn{2}{|c|}{$\begin{array}{l}\text { Subsurface } \\
\text { (groundwater) }\end{array}$}} & $\begin{array}{l}\text { C1 Eskers \& moraines } \\
\text { E Surface sediments } \\
\text { near eskers }\end{array}$ & $\begin{array}{l}\text { (5) Unconfined granular } \\
\text { aquifer }\end{array}$ \\
\hline & & $\begin{array}{l}\text { D Glaciolacustrine clay } \\
\& \text { silt }\end{array}$ & Regional aquitard \\
\hline & & $\begin{array}{l}\text { C2 Sediments } \\
\text { underlying clay }\end{array}$ & $\begin{array}{l}\text { (6) Confined granular } \\
\text { aquifer }\end{array}$ \\
\hline & & $\underline{\mathrm{B}}$ Till & - \\
\hline & & $\underline{\text { A Fractured rock }}$ & $\begin{array}{l}\text { (7) Unconfined } \\
\text { or }(8) \text { confined fractured } \\
\text { rock aquifer }\end{array}$ \\
\hline
\end{tabular}




\begin{tabular}{|c|c|c|}
\hline Type of samples & $\begin{array}{l}\text { Number of } \\
\text { samples }(\mathrm{n})\end{array}$ & Sampling timeline \\
\hline Precipitation & 164 & $\begin{array}{l}\text { Monthly samples at four stations } \\
2009-2015\end{array}$ \\
\hline Snowpack & 31 & March $2014(n=31)$ \\
\hline Springs & 76 & $\begin{array}{l}\text { Summer } 2009(n=30) \\
\text { Summer-Autumn } 2010(n=41) \\
\text { Summer-Autumn } 2013(n=5)\end{array}$ \\
\hline Kettle lakes & 14 & Summer $2009(n=14)$ \\
\hline Surface waters & 85 & Summer-Autumn $2013(\mathrm{n}=85)$ \\
\hline $\begin{array}{r}\text { Confined fractured rock } \\
\text { aquifer }\end{array}$ & 105 & $\begin{array}{l}\text { Summer-Autumn } 2006(n=14) \\
\text { Summer-Autumn } 2010(n=26) \\
\text { Summer } 2013(n=65)\end{array}$ \\
\hline $\begin{array}{r}\text { Unconfined fractured rock } \\
\text { aquifers }\end{array}$ & 38 & $\begin{array}{l}\text { Autumn } 2006(n=2) \\
\text { Summer } 2010(n=7) \\
\text { Summer-Autumn } 2013(n=29)\end{array}$ \\
\hline Confined granular aquifers & 53 & $\begin{array}{l}\text { Summer-Autumn } 2006(n=2) \\
\text { Summer-Autumn } 2010(n=15) \\
\text { Summer } 2013(n=36)\end{array}$ \\
\hline $\begin{array}{r}\text { Unconfined granular } \\
\text { aquifers }\end{array}$ & 79 & $\begin{array}{l}\text { Summer-Autumn } 2006(n=2) \\
\text { Summer } 2009(n=14) \\
\text { Summer-Autumn 2010 }(n=25) \\
\text { Autumn } 2011(n=15) \\
\text { Summer-Autumn 2013 }(n=23)\end{array}$ \\
\hline Total & 645 & $2006-2015$ \\
\hline
\end{tabular}




\begin{tabular}{|c|c|c|c|}
\hline $\begin{array}{c}\text { Surface } \\
\text { waters }\end{array}$ & Names & Sampling techniques & Dates \\
\hline $\begin{array}{l}\text { Kettle } \\
\text { lakes }\end{array}$ & - & \multirow{3}{*}{$\begin{array}{l}1 \mathrm{~m} \text { from the lake shore / Telescopic pole / 0.5- } \\
\qquad 1.5 \mathrm{~m} \text { below surface }\end{array}$} & Summer 2009 \\
\hline \multirow{4}{*}{$\begin{array}{l}\text { Fault } \\
\text { Lakes }\end{array}$} & Opasatica & & \multirow{3}{*}{ Summer 2013} \\
\hline & Rémigny & & \\
\hline & Témiscamingue & Boat / Telescopic pole / 0.5-1.5 m below surface & \\
\hline & Tee & $\begin{array}{l}\text { Boat / Plastic tubing equipped with an inertial } \\
\text { valve / } 0.5-1.5 \mathrm{~m} \text { below surface }\end{array}$ & Autumn 2013 \\
\hline \multirow{2}{*}{$\begin{array}{l}\text { Lakes on } \\
\text { clay }\end{array}$} & Macamic & \multirow{2}{*}{$\begin{array}{l}\text { Sampling at the outlet of the lake / Telescopic } \\
\text { pole / } 0.5-1.5 \mathrm{~m} \text { below surface }\end{array}$} & \multirow{10}{*}{ Summer 2013} \\
\hline & Abitibi & & \\
\hline \multirow{8}{*}{ Rivers } & Outaouais & $\begin{array}{l}\text { Boat / Telescopic pole / central part of the main } \\
\text { channel / } 0.5-1.5 \mathrm{~m} \text { below surface }\end{array}$ & \\
\hline & Duparquet & \multirow{7}{*}{$\begin{array}{c}\text { Sampling near the central part of the main } \\
\text { channel / Telescopic pole or Bailer / 0.5-1.5 m } \\
\text { below surface }\end{array}$} & \\
\hline & La Sarre & & \\
\hline & $\begin{array}{l}\text { From lac Mance } \\
\end{array}$ & & \\
\hline & Between Beauchastel and Montbeillard lakes & & \\
\hline & Between Routier and Vallet lakes & & \\
\hline & Between Rondelet and Des Quinze lakes & & \\
\hline & Between two lakes (Mont Brun sector) & & \\
\hline $\begin{array}{l}\text { Small } \\
\text { streams }\end{array}$ & - & $\begin{array}{c}\text { Sampling near the central part of the main } \\
\text { channel / Telescopic pole or Bailer / 0.5-1.5 m } \\
\text { below surface }\end{array}$ & Summer/Autumn 2013 \\
\hline
\end{tabular}




\begin{tabular}{ll}
\hline \multicolumn{1}{c}{ In situ parameters } & \multicolumn{1}{c}{ Stability criteria } \\
\hline Temperature $\left({ }^{\circ} \mathrm{C}\right)$ & \pm 0.1 \\
pH (pH unit) & \pm 0.1 \\
Specific electrical conductivity $(\mu \mathrm{S} / \mathrm{cm})$ & $\pm 2 \%$ \\
Dissolved oxygen $(\mathrm{mg} / \mathrm{L})$ & \pm 0.2 \\
Redox potential $(\mathrm{mV})$ & \pm 10 \\
Turbidity (visual observation) & Constant color/opacity \\
\hline
\end{tabular}




\begin{tabular}{llcc}
\hline \multicolumn{1}{c}{ Stations } & $\mathrm{n}$ & $\begin{array}{c}\delta^{2} \mathrm{H} \\
(\% \text { VSMOW })\end{array}$ & $\begin{array}{c}\delta^{18} \mathrm{O} \\
(\% \text { VSMOW })\end{array}$ \\
\hline Station 1 (Béarn) & 24 & -91.9 & -13.0 \\
Station 2 (Montbeillard) & 13 & $\mathrm{NA}$ & $\mathrm{NA}$ \\
Station 3 (Sainte-Hélène-de-Mancebourg) & 24 & -100.9 & -14.2 \\
Station 4 (Amos) & 24 & -84.5 & -12.0 \\
\hline
\end{tabular}

Refer to Figure 1 for stations locations; n: number of samples.

NA: averages values are not provided owing to a lack of data from November to April. 


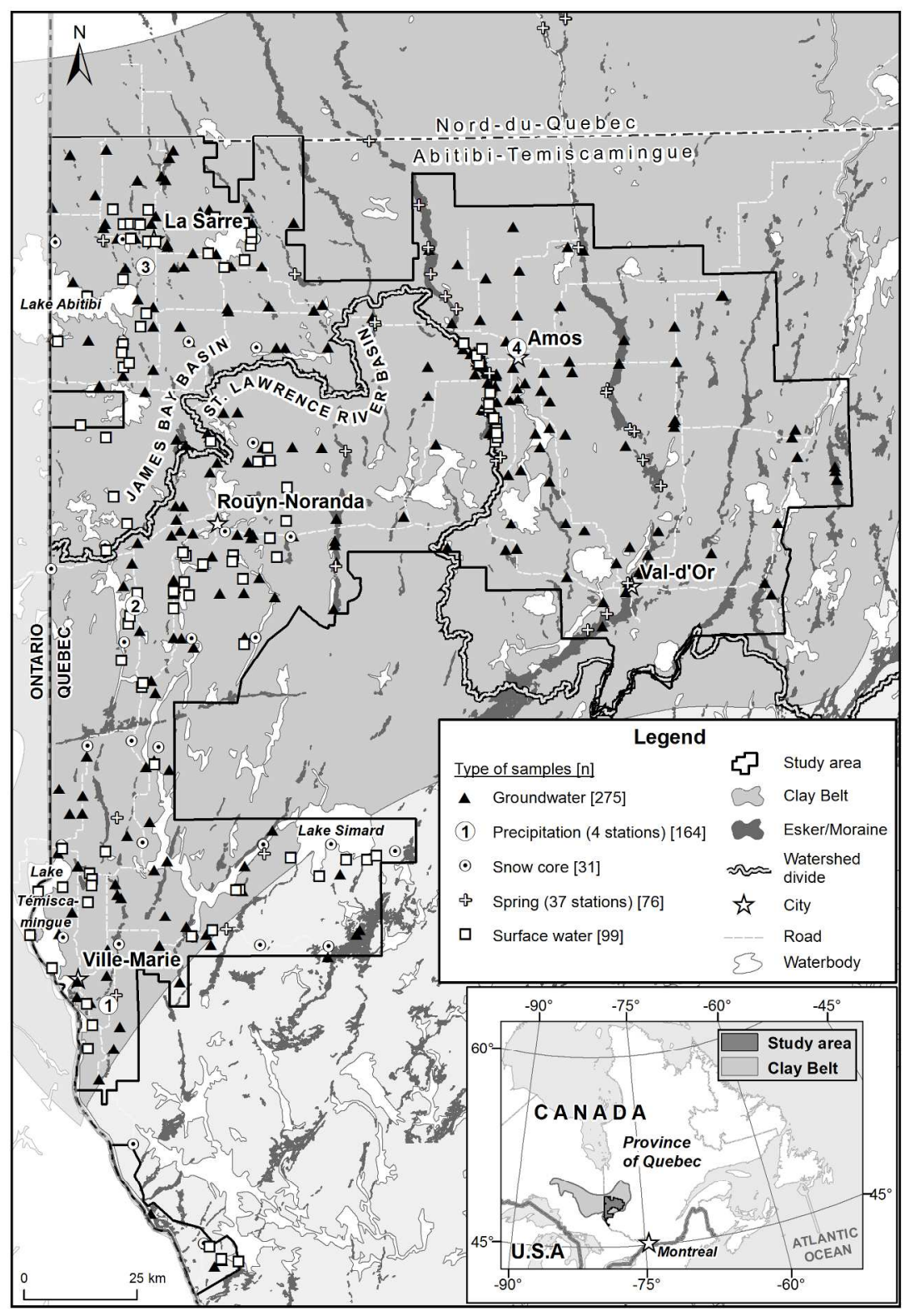

Figure 1 . Study area with the location of sampling sites. The number $(n)$ of available samples is shown brackets in the legend. The limits of the study area correspond to that of previous studies from Cloutier et al. (2013; 2015). The continental water divide between the St. Lawrence and the James Bay basins is also shown.

$190 \times 270 \mathrm{~mm}(300 \times 300 \mathrm{DPI})$ 


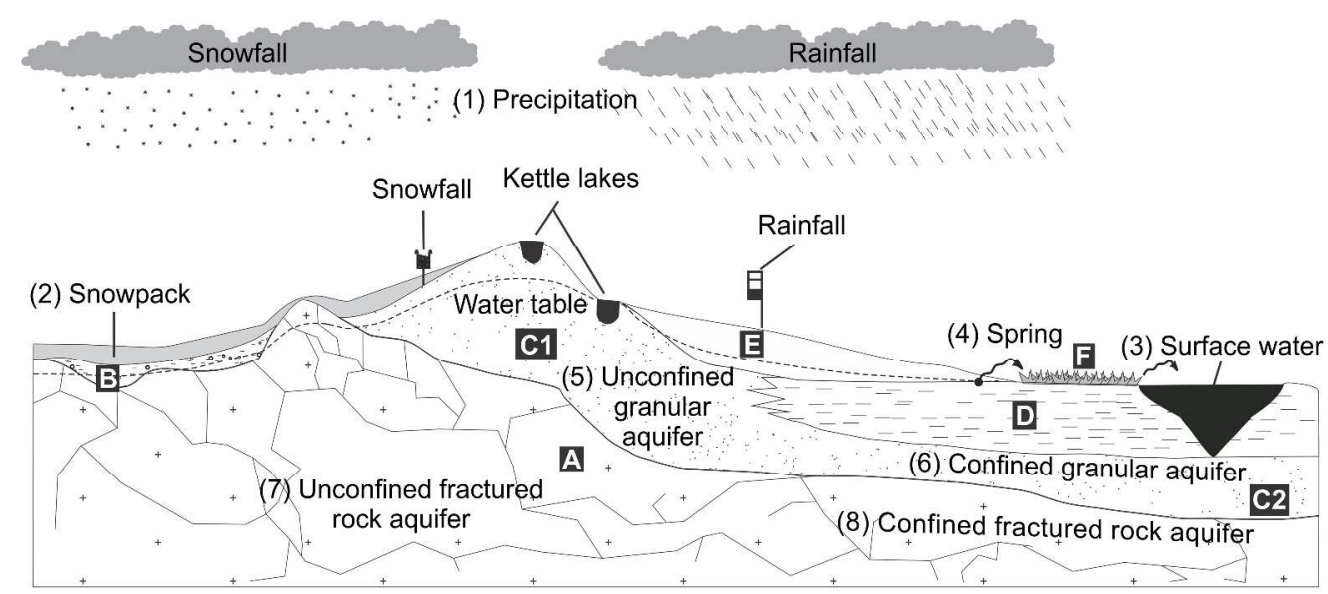

Figure 2. Regional hydrogeological conceptual model and water sampling scheme used to characterize the isotopic signature of all hydrological system components. (A) Fractured bedrock; (B) Till; (C1) Eskers and moraines; (C2) glaciofluvial sediments found between eskers and moraines, under the clay plain; (D) fine grained deep-water glaciolacustrine sediments; (E) Sublittoral sands and beach or eolian sediments; (F)

Organic deposits. The numbers ( 1 to 8 ) correspond to the sampled hydrological components and hydrogeological units, as identified in table 1.

$417 \times 182 \mathrm{~mm}(300 \times 300 \mathrm{DPI})$ 


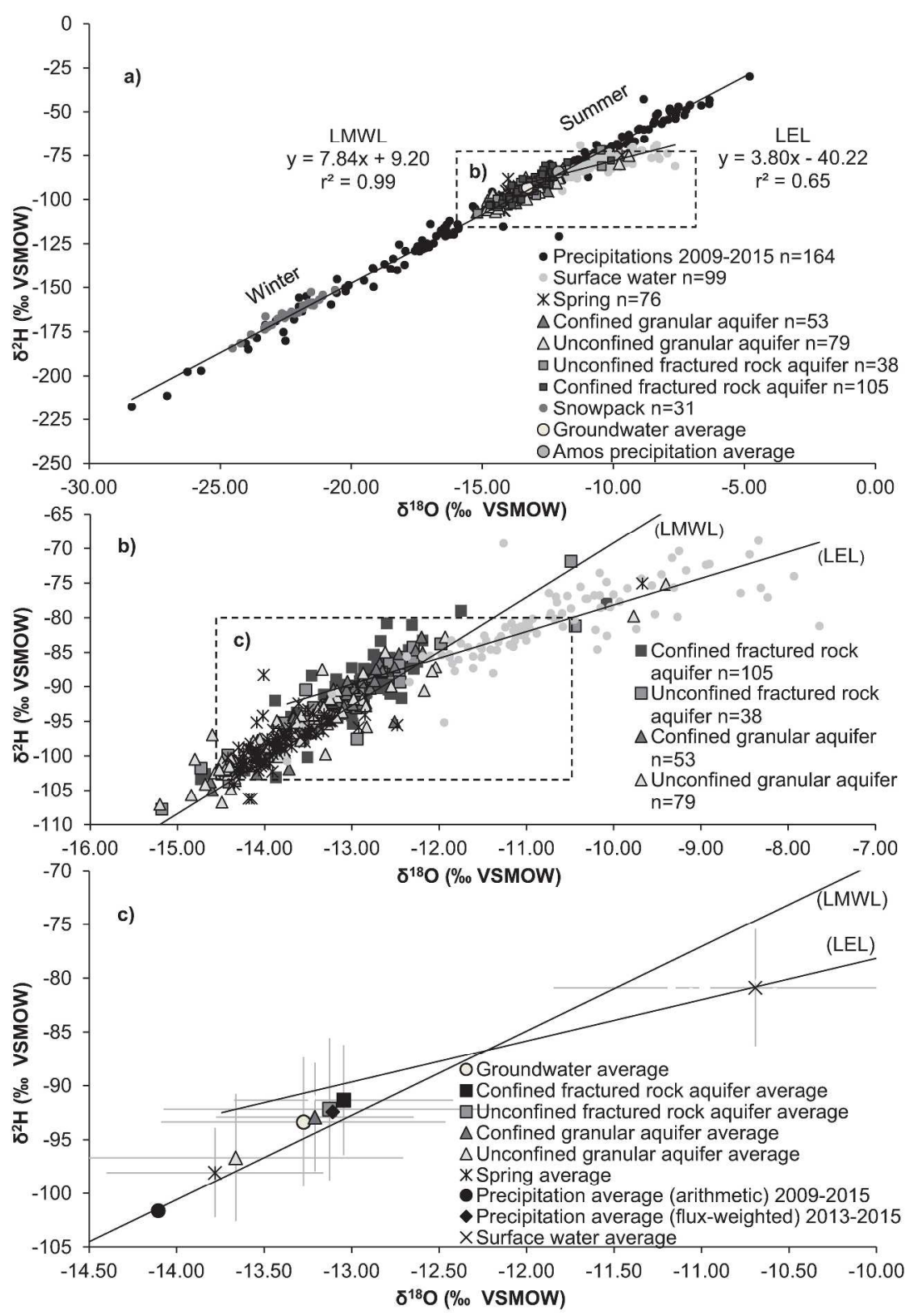

Figure 3. Isotopic composition of precipitation, surface waters, springs and groundwater. All data are shown in (a) whereas figure (b) provides a zoom on the surface and groundwater data. Average values are provided in figure (c). The flux-weighted average for precipitation is based on the three stations (SainteHélène-de-Mancebourg, Amos, Bearn) where precipitation samples were collected between 2013-2015. The value correspond to the mean of the flux-weighted averages calculated for each station. The arithmetic average calculated for all precipitation samples is also shown. The error bars in (c) correspond to the standard deviation calculated for each sample series. The local meteoric water line (LMWL) and local evaporation line (LEL) derived from the data are also shown.

$275 \times 397 \mathrm{~mm}(300 \times 300$ DPI $)$ 

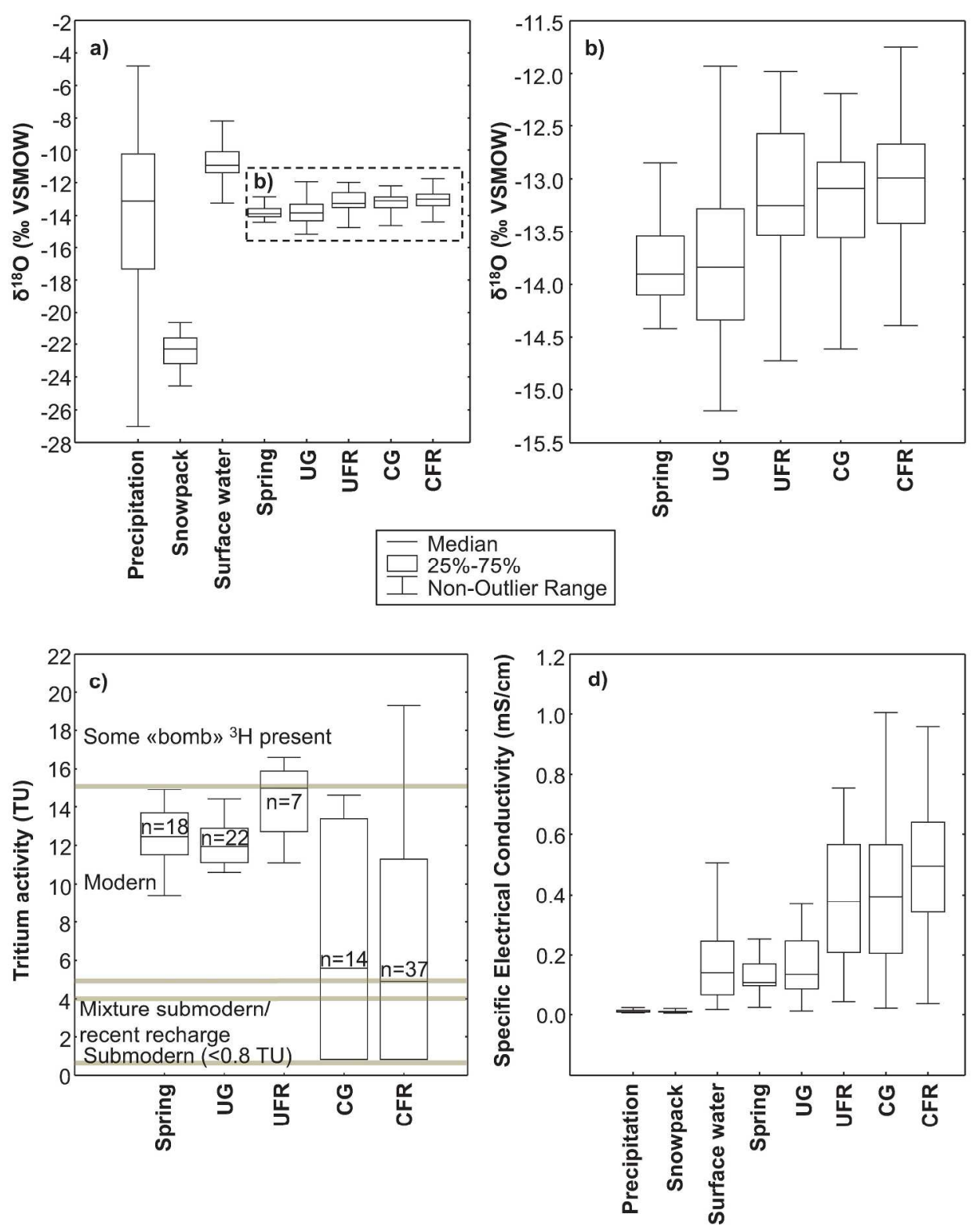

Figure 4. $\delta^{18} \mathrm{O}(\mathrm{a} ; \mathrm{b}),{ }^{3} \mathrm{H}(\mathrm{c})$ and SEC (d) boxplots for precipitation, surface waters, springs and groundwater. Outlier data are excluded; the non-outlier range is defined as maximum and minimum values within 1.5 times the interquartile range. The available $\delta^{18} \mathrm{O}$ data are shown in (a) whereas a clearer view of surface and groundwater data is provided in (b). The classification reported in (c) is adapted from Clark and

Fritz (1997). UG: unconfined granular aquifers; UFR: unconfined fractured rock aquifers; CG: confined granular aquifers; CFR: confined fractured rock aquifers; SEC: specific electrical conductivity. In (a) and

(d), the samples collected from the snowpack and at the precipitation monitoring stations are shown separately.

$$
239 \times 301 \mathrm{~mm}(300 \times 300 \text { DPI) }
$$




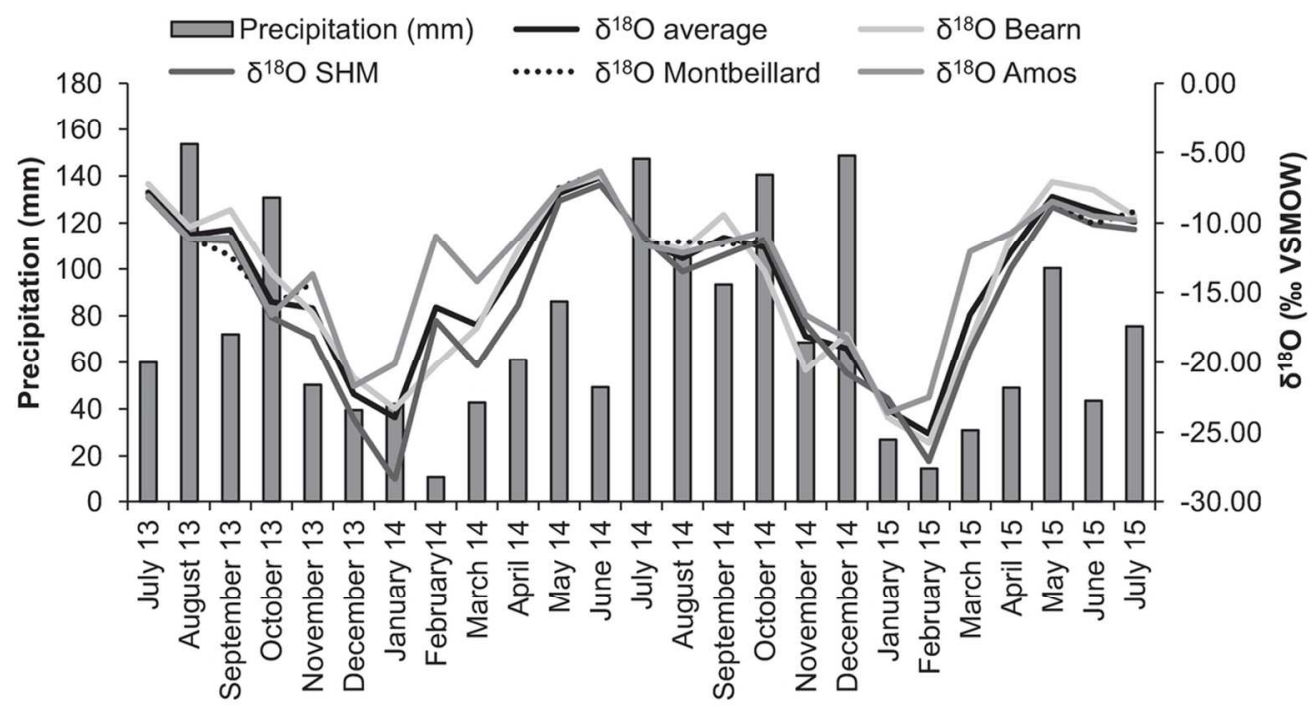

Figure 5. Seasonal variations in precipitation amounts and $\delta^{18} \mathrm{O}$ composition. See figure 1 for the location of monitoring stations. The histogram showing precipitation amounts is based on data from July 2013 to July 2015 as recorded at the monitoring stations. SHM: Sainte-Hélène-de-Mancebourg.

$104 \times 57 \mathrm{~mm}(300 \times 300 \mathrm{DPI})$ 

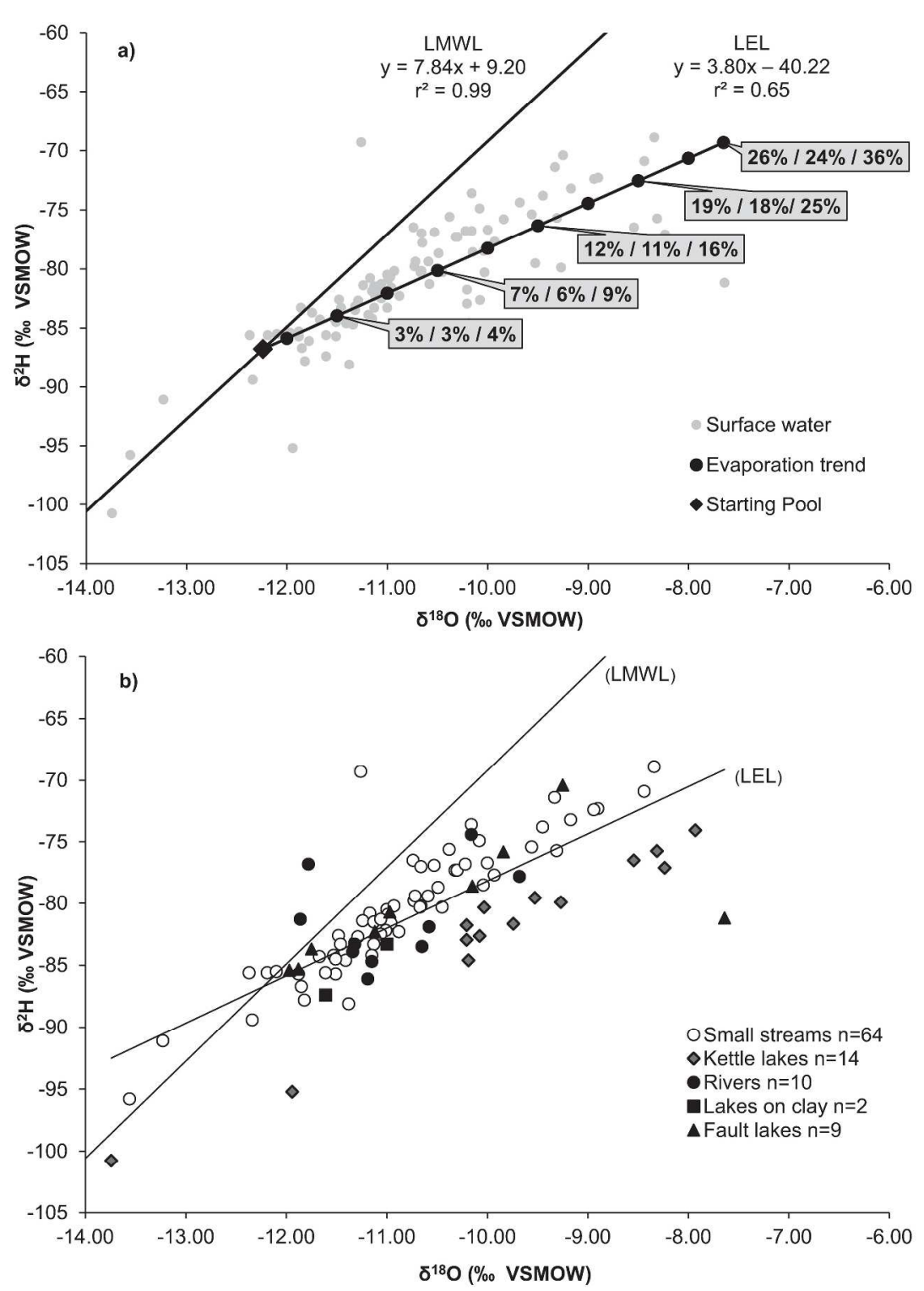

Figure 6. Interpretation of the isotopic compositions of surface waters. Data in (a) represent the local evaporation line evaluated using the 99 available surface water samples. The E/I ratios are shown for points plotting on the LEL at $0.5 \%$ intervals along the x-axis. These E/I ratios are shown for three scenarios (see text for details). Further details with respect to the types of surface water samples are provided in (b) and in table 3.

$275 \times 397 m m(300 \times 300$ DPI) 


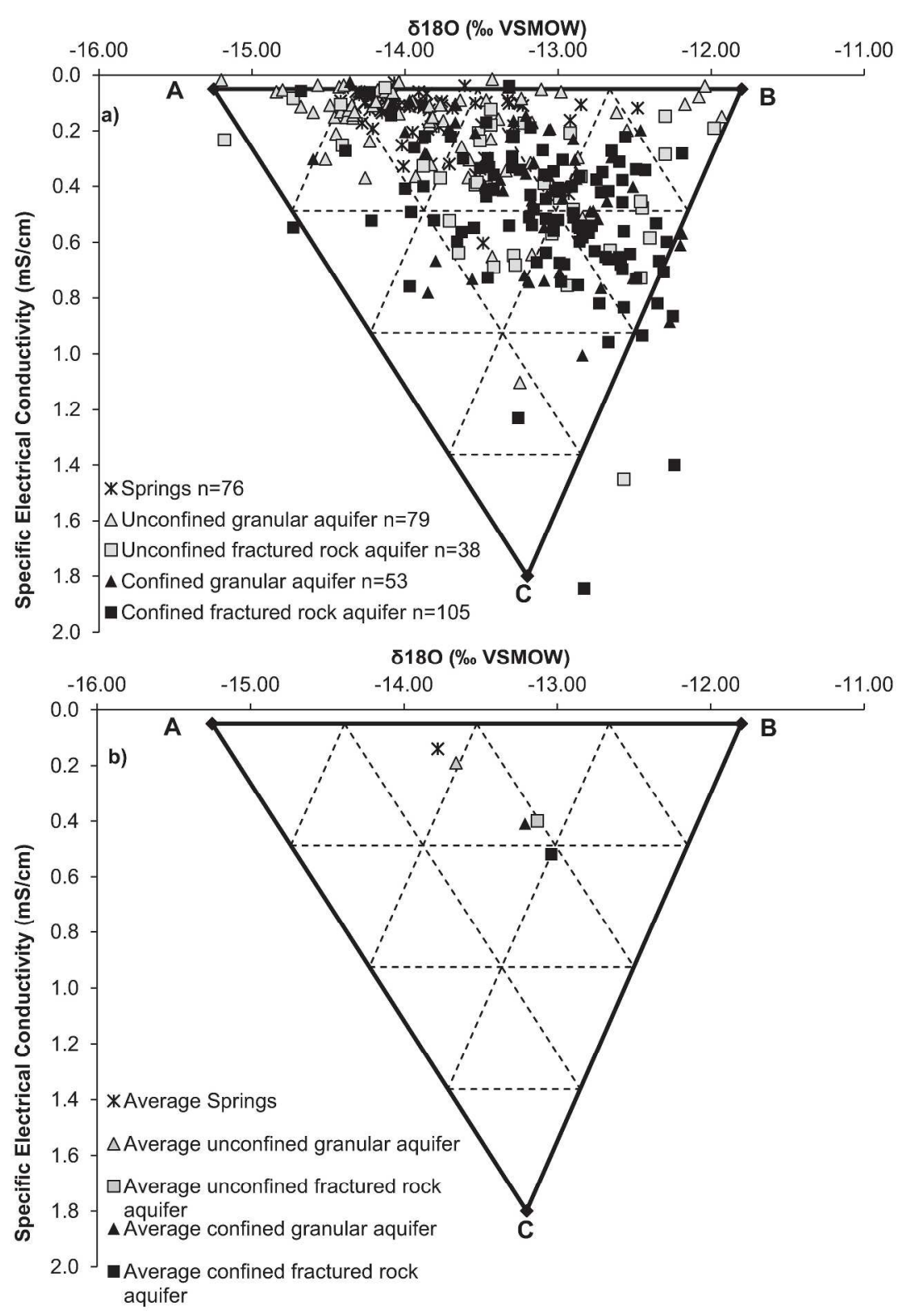

Figure 7. Specific electrical conductivity (SEC) vs $\delta^{18} \mathrm{O}$ of springs, surface waters and groundwater. Three end-members are shown: «A» corresponds to groundwater recharged during snowmelt, «B» corresponds to groundwater that is less impacted by snowmelt induced recharge and «C evolved groundwater found further along regional flowpaths. See text for further details. The six main outliers (as described in the text) are not shown in this figure. Figure (a) shows the distribution of data whereas the corresponding averages are shown in (b).

$$
263 \times 365 \mathrm{~mm}(300 \times 300 \mathrm{DPI})
$$



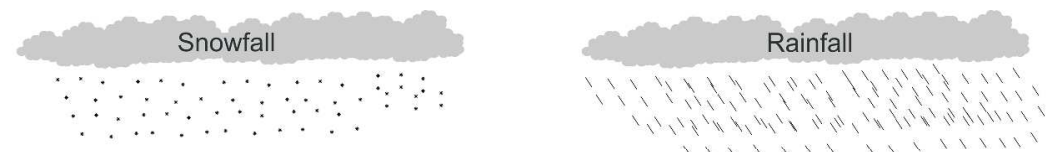

Recharge areas / precipitations input : $-27 \% 0<\delta^{18} 0<-4.5 \%$ (1)

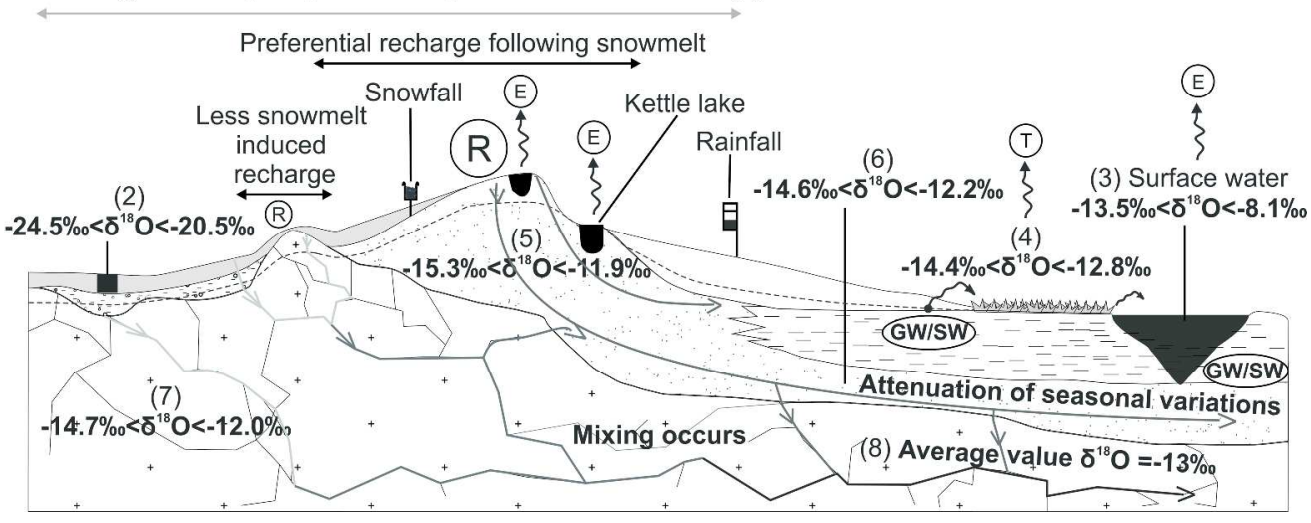

Figure 8. Isotopic variations within local, intermediate and regional flow systems. The range of measured isotopic compositions is shown for the sampled hydrological components and hydrogeological units, as identified in tables 1 and 2. Areas of preferential snowmelt induced recharge are identified. Flowpaths at various scales are shown. (R) Recharge area; (E) Evaporation; (T) Transpiration; (GW/SW) Groundwater / surface water interactions (herein mainly groundwater exfiltration). The numbers (1 to 8 ) correspond to the sampled hydrological components and hydrogeological units, as identified in table 1.

$423 \times 226 \mathrm{~mm}(300 \times 300 \mathrm{DPI})$ 